\title{
Seascape ecology of coastal biogenic habitats: advances, gaps, and challenges
}

\author{
Christoffer Boström ${ }^{1, *}$, Simon J. Pittman ${ }^{2,3}$, Charles Simenstad ${ }^{4}$, Ronald T. Kneib ${ }^{5,6}$ \\ ${ }^{1}$ Åbo Akademi University, Department of Biosciences, Environmental and Marine Biology, Artillerigatan 6, 20520 Åbo, \\ Finland \\ ${ }^{2}$ National Oceanic \& Atmospheric Administration Biogeography Branch, 1305 East-West Highway, Silver Spring, Maryland \\ 20910, USA \\ ${ }^{3}$ University of the Virgin Islands, Marine Science Center, 2 John Brewer's Bay, St. Thomas, US Virgin Islands 00802, USA \\ ${ }^{4}$ School of Aquatic and Fishery Sciences, Box 355020, University of Washington, Seattle, Washington 98195-5020, USA \\ ${ }^{5}$ University of Georgia Marine Institute, Sapelo Island, Georgia 31327, USA \\ ${ }^{6}$ RTK Consulting Services, 10 Taza Trail, Hillsboro, New Mexico 88042, USA
}

\begin{abstract}
We review the progress made in the emerging field of coastal seascape ecology, i.e. the application of landscape ecology concepts and techniques to the coastal marine environment. Since the early 1990s, the landscape ecology approach has been applied in several coastal subtidal and intertidal biogenic habitats across a range of spatial scales. Emerging evidence indicates that animals in these seascapes respond to the structure of patches and patch mosaics in different ways and at different spatial scales, yet we still know very little about the ecological significance of these relationships and the consequences of change in seascape patterning for ecosystem functioning and overall biodiversity. Ecological interactions that occur within patches and among different types of patches (or seascapes) are likely to be critically important in maintaining primary and secondary production, trophic transfer, biodiversity, coastal protection, and supporting a wealth of ecosystem goods and services. We review faunal responses to patch and seascape structure, including effects of fragmentation on 5 focal habitats: seagrass meadows, salt marshes, coral reefs, mangrove forests, and oyster reefs. Extrapolating and generalizing spatial relationships between ecological patterns and processes across scales remains a significant challenge, and we show that there are major gaps in our understanding of these relationships. Filling these gaps will be crucial for managing and responding to an inevitably changing coastal environment. We show that critical ecological thresholds exist in the structural patterning of biogenic ecosystems that, when exceeded, cause abrupt shifts in the distribution and abundance of organisms. A better understanding of faunal-seascape relationships, including the identifications of threshold effects, is urgently needed to support the development of more effective and holistic management actions in restoration, site prioritization, and forecasting the impacts of environmental change.
\end{abstract}

KEY WORDS: Landscape ecology $\cdot$ Seascape $\cdot$ Fragmentation $\cdot$ Scale $\cdot$ Edge effects $\cdot$ Patch size Thresholds · Connectivity

\section{INTRODUCTION}

Landscape ecology is a multidisciplinary field that combines the spatial approach of geography with functional ecology. For terrestrial ecosystems, landscape ecology has provided an important conceptual and analytical framework to understand ecology through a focus on understanding the causes and ecological consequences of spatial patterns in the environment (Wiens 1995b, Turner 2005). The unique spatiallyexplicit and multi-scale framework of landscape ecology has influenced our perception of species-envi- 
ronment relationships and has led to significant advancements in the design of terrestrial conservation strategies worldwide (Wiens 1999, Liu \& Taylor 2002). More recently, landscape ecology has been explicitly incorporated into coastal conservation strategies such as marine protected area (MPA) network design (Leslie 2005, Leathwick et al. 2008).

There are many ways to define a landscape, but from an ecological perspective a landscape is an area of land containing a mosaic of habitat patches, often within which a particular 'focal' or 'target' habitat patch is embedded (Dunning et al. 1992). More broadly, we define a seascape as a spatially heterogeneous area of coastal environment (i.e. intertidal, brackish) that can be perceived as a mosaic of patches, a spatial gradient, or some other geometric patterning quantified from either benthic or pelagic environments. Seascape structure is commonly represented as a patch matrix, with focal patches (e.g. vegetation) viewed as 'islands' embedded in a matrix (e.g. sediment) that affects animal movements and survival depending on relative isolation. This model, derived from the theory of island biogeography (MacArthur \& Wilson 1967), has proven useful in studies of seagrass meadows depicted as simplified binary seascapes, whereby seagrasses are focal patches and the surrounding unvegetated sand is the matrix (McNeill \& Fairweather 1993, Robbins \& Bell 1994). In particular, the patch matrix model has been applied to study the spatial processes and ecological consequences of fragmentation in seagrass meadows measured by changes in seagrass patch size, the number of patches, and their relative isolation (Bell et al. 2001, Hovel \& Regan 2008). In contrast, the patch mosaic model is a competing construct that represents structural heterogeneity as a collection of different patch types, where the interactions of the parts influence the ecological function of the whole mosaic (Wiens et al. 1993, Wiens 1995a). In the patch mosaic model, a homogeneous matrix does not exist and instead the composition (abundance and variety of patch types) and spatial configuration (geometric structure) of mosaics is of central importance. In addition, an important third model has recently emerged that represents structural heterogeneity as a continuous gradient without discrete patch boundaries, such as with a digital terrain model of bathymetry or sea surface temperature (McGarigal \& Cushman 2002, Pittman et al. 2009).

Despite the demonstrated applicability of landscape ecology concepts and techniques to coastal environments, particularly in shallow-water benthic ecosystems, seascape ecology has only slowly emerged during the past 2 decades, with relatively few practitioners and limited impact on mainstream marine ecology (Johnson \& Gage 1997, Wiens 2002, Turner 2005).
From the historical perspective of terrestrial landscapes, aquatic ecosystems were simply elements in the broader landscape, resulting in a lag in the application of landscape concepts to submerged ecosystems (Kneib 1994). Increasingly, however, coastal ecologists and managers are asking complex multi-scale questions that can best be addressed with a landscape ecology approach. Thus, we suggest that many of the central concepts and analytical approaches developed for terrestrial applications are equally applicable to the study of aquatic benthic environments, including both semi-terrestrial environments of the shoreline (salt marshes) and subtidal and intertidal seascapes composed of e.g. coral reefs and molluskan reefs. Many coastal organisms are closely associated with benthic structure, which is analogous to a land surface. Although submersion in water rather than air likely has a different effect on mobility, dispersal, and rates of ecological processes, variation in seascape structure (e.g. patch dynamics, edges, and proximity of one patch type to another) is intuitively and empirically known to influence coastal fauna. As the body of knowledge in seascape ecology expands, syntheses and meta-analyses are important in identifying generalities emerging from faunal responses to spatial patterning, and for comparing spatially-explicit responses in coastal environments.

Coastal environments are of major importance for secondary production, trophic transfer, and coastal biodiversity (Hughes et al. 2009). They may also provide the highest economic value of all natural ecosystems (Costanza et al. 1997, McArthur \& Boland 2006, Duarte 2009) (Table 1). Intertidal marshes and mangrove forests represent critical transition zones linking terrestrial and coastal environments and often control the fluxes of materials and energy across landseascapes (Valiela et al. 2000, Ewel et al. 2001, Levin et al. 2001). Furthermore, many important coastal biogenic habitats (e.g. tidal marshes, seagrass meadows, and coral reefs) occur in close proximity to densely populated coastal regions and as such are now among the most heavily used and impacted environments on earth (Weslawski et al. 2004, Lotze et al. 2006). Annual loss rates of the 5 most important biogenic habitats range between 1 and $9 \%$ (Duarte et al. 2008). Total global loss estimates of seagrasses, salt marshes, coral reefs, and mangroves average 30\% (Nicholls et al. 1999, Valiela et al. 2001, Wilkinson 2008, Waycott et al. 2009), and losses of oyster reefs may exceed $85 \%$ (Beck et al. 2009) (Table 1). Loss drivers often involve multiple interacting stressors (Table 2), including localized impacts such as mariculture, dredging, pollution, and species invasions, as well as broader-scale impacts such as over-harvesting, watershed development, and global climate change (Snelgrove et al. 2004). Several 
negative feedback links between ecosystem goods and services and loss drivers exist. For example, as many biogenic habitats support food resources critical for humanity, impacts such as mangrove mariculture further accelerate habitat loss, which, in turn, impairs other ecosystem goods and services. The negative impacts operate across a range of scales in time and space, and affect the integrity of coastal ecosystems in ways that are not yet fully understood.
While the consequences of total habitat loss for associated communities are becoming well documented (Airoldi \& Beck 2007), there is little understanding of how coastal organisms respond to fragmentation and other changes in the spatial configuration of ecosystems, or whether responses are similar across ecosystems and taxa. In addition, the fact that spatial patterning of biogenic habitats can be perceived and quantified at a range of scales across a spatial hier-

Table 1. Summary of total global loss, annual loss rates, global diversity, loss drivers, and examples of ecosystems goods and services provided by the coastal biogenic ecosystems included in this review. Loss drivers and ecosystem services are not ranked in order of importance, as the relative role of each factor in each ecosystem might vary greatly between regions. Data sources: ${ }^{\mathrm{a}}$ Waycott et al. (2009); ${ }^{\mathrm{b}}$ Nicholls et al. (1999); Solomon et al. (2007); ${ }^{\mathrm{C}}$ Wilkinson (2008). ${ }^{\mathrm{d}}$ Oyster diversity refers to a minimum number of native, wild reef-forming oyster species in a global risk assessment (Beck et al. 2009), not the total global oyster species diversity; ${ }^{\text {e}}$ Valiela et al. (2001); ${ }^{\mathrm{f}}$ Waycott et al. (2009); ${ }^{9}$ Duarte et al. (2008); ${ }^{\mathrm{h}}$ Duarte et al. (2008); ${ }^{\mathrm{i}}$ Valiela et al. (2009); ${ }^{\mathrm{j}}$ Dennison

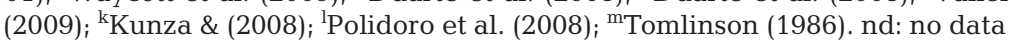

\begin{tabular}{|lclccc|}
\hline & Seagrass meadows & Salt marshes & Coral reefs & Oyster reefs & Mangrove forests \\
\hline Global loss (\%) & $29^{\mathrm{a}}$ & $13-30^{\mathrm{b}}$ & $34^{\mathrm{c}}$ & $85^{\mathrm{d}}$ & $35^{\mathrm{e}}$ \\
Annual loss rate (\%) & $7^{\mathrm{f}}$ & $1-2^{\mathrm{g}}$ & $4-9^{\mathrm{h}}$ & nd & $2.1-3.6^{\mathrm{i}}$ \\
Diversity & $60^{\mathrm{j}}$ & $43^{\mathrm{k}}$ & $845^{\mathrm{l}}$ & $\sim 40^{\mathrm{d}}$ & $75^{\mathrm{m}}$ \\
Loss drivers & Eutrophication & Construction & Acidification & Overfishing & $\begin{array}{c}\text { Mariculture } \\
\end{array}$ \\
& Dredging & Sea level rise & Eutrophication & Disease & Construction \\
& Mooring & Die-back & Climate change & Sedimentation & Forestry \\
& Overfishing & Invasive species & Overfishing & Eutrophication & Sea level rise \\
Ecosystem goods & Biodiversity & Biodiversity & Biodiversity & Food & Food \\
and services & Food & Food & Food/Fisheries & Biodiversity & Timber \\
& Export of materials & Export of materials & Ecotourism & Stabilization & Biodiversity \\
& Ecotourism & Ecotourism & Stabilization & Filtering & Ecotourism \\
& Stabilization & Stabilization & Carbon & Carbon and nutrient Stabilization \\
& Carbon and nutrient & Contaminant and & sequestration & sequestration & Carbon and nutrient \\
& sequestration & nutrient interception & & & sequestration \\
\hline
\end{tabular}

Table 2. Summary of mechanisms causing habitat fragmentation in coastal biogenic habitats. Sum scores from 1 to 5 indicate low to high generality of specific fragmentation mechanisms across systems. Note that habitat fragmentation also involves positive effects in terms of population growth by spatial spread through seedlings, colony fragments, and recruiting individuals

\begin{tabular}{|c|c|c|c|c|c|c|c|}
\hline $\begin{array}{l}\text { Disturbance } \\
\text { type }\end{array}$ & $\begin{array}{l}\text { Fragmentation } \\
\text { mechanism }\end{array}$ & $\begin{array}{l}\text { Seagrass } \\
\text { meadow }\end{array}$ & $\begin{array}{l}\text { Salt } \\
\text { marsh }\end{array}$ & $\begin{array}{l}\text { Coral } \\
\text { reef }\end{array}$ & $\begin{array}{c}\text { Mangrove } \\
\text { forest }\end{array}$ & $\begin{array}{l}\text { Oyster } \\
\text { reef }\end{array}$ & Sum \\
\hline \multirow[t]{9}{*}{ Physical } & Storm events/sand scour & + & + & + & + & + & 5 \\
\hline & Tsunami & + & + & + & + & + & 5 \\
\hline & Construction & + & + & + & + & + & 5 \\
\hline & Dredging & + & + & & & + & 3 \\
\hline & Hydrologic alterations & & + & & + & + & 3 \\
\hline & Siltation/sedimentation & + & & + & & + & 3 \\
\hline & Propeller scarring & + & & & & + & 2 \\
\hline & Anchoring & + & & & & & 1 \\
\hline & Loss of adjacent habitat & & & & & + & 1 \\
\hline \multirow[t]{8}{*}{ Biological } & Natural spreading & + & + & + & + & + & 5 \\
\hline & Invasive species & + & & & & + & 2 \\
\hline & Grazing/bioerosion & + & & + & & & 2 \\
\hline & Diseases and parasites & + & & & & + & 2 \\
\hline & Overfishing & + & & + & & & 2 \\
\hline & Competition & + & & + & & & 2 \\
\hline & Bioturbation & + & & & & & 1 \\
\hline & Bleaching & & & + & & & 1 \\
\hline \multirow{2}{*}{ Chemical } & Eutrophication & + & & + & & & 2 \\
\hline & Toxic compounds & + & + & + & + & + & 5 \\
\hline
\end{tabular}




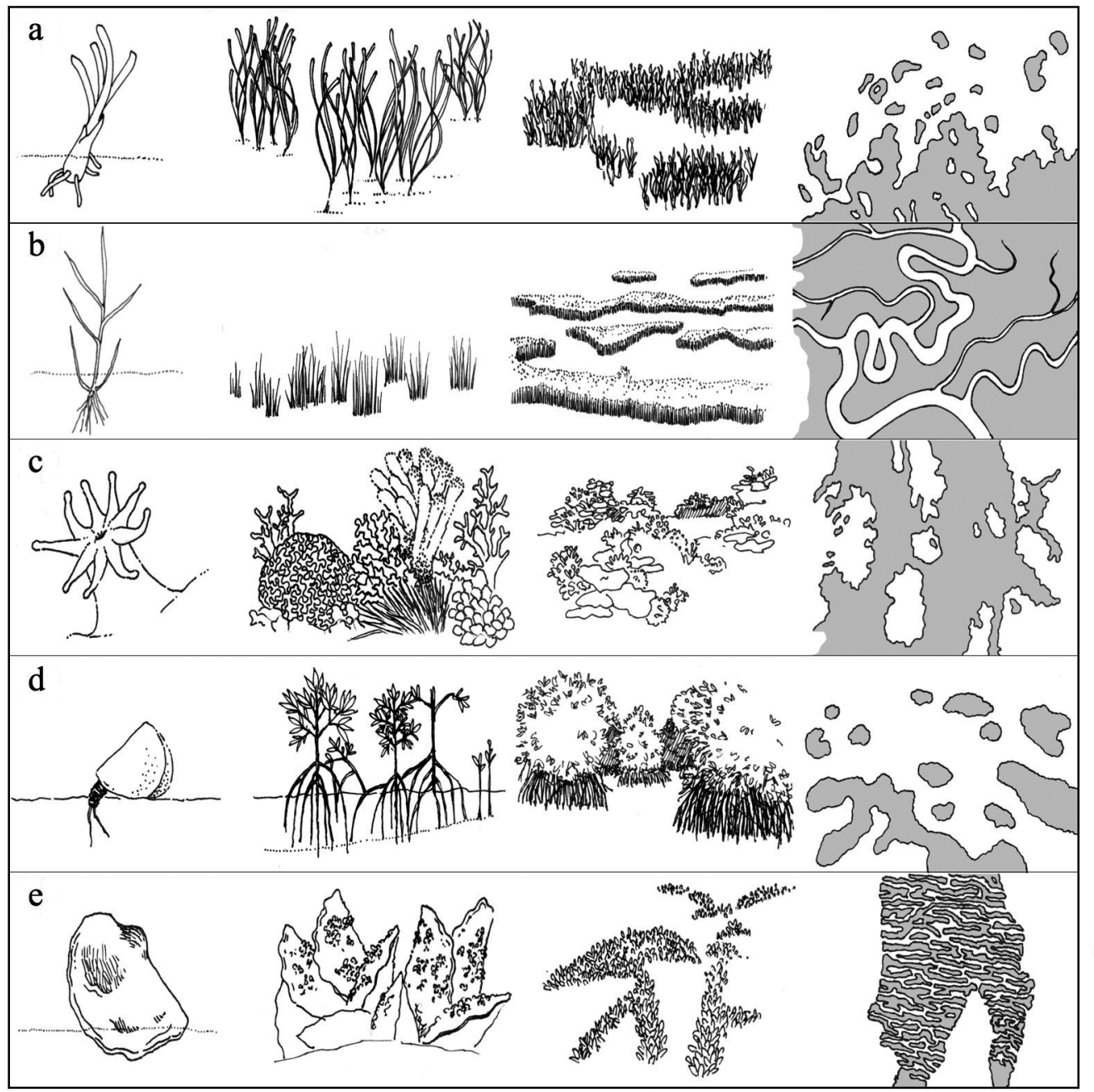

Fig. 1. What is a patch? Artistic representation of the hierarchical structure of the 5 coastal biogenic habitats studied: (a) seagrass, (b) salt marsh, (c) coral reef, (d) mangrove, and (e) oyster reef. For comparative purposes, figures are not drawn to scale. The dimension of the study area (extent) increase from left to right $(1-10 \mathrm{~cm}, 10 \mathrm{~cm}-10 \mathrm{~m}$, $10-100 \mathrm{~s} \mathrm{~m}, 100 \mathrm{~s} \mathrm{~m}-$ $10 \mathrm{~s} \mathrm{~km}$ ) while resolution (grain) increases from right to left. The vertical dimensions of habitats range from a few centimeters (seedlings and oyster shells) to several meters (mangroves and coral reefs)

archy (Fig. 1) adds ambiguity to the use of terms such as 'patch' and 'fragmentation,' further complicating interpretation of responses across habitats. We adopt the definition of habitat fragmentation as being a complex process (not a state) seldom resulting in the mere splitting of habitat, but involving multiple changes such as habitat loss, increased isolation, and changes in patch quality (Fahrig 2003).

Most coastal biogenic habitats exist as components of functionally connected coastal mosaics, so loss or degradation of a particular habitat is likely to impair the integrity of neighboring patches and disrupt links in the ecosystem as a whole. For example, seagrass meadows and salt marshes play a significant role by subsidizing energy to adjacent and even distant ecosystems (Kneib 2000, Guest \& Connolly 2006, Heck et al. 2008, Meynecke et al. 2008). For seagrass-associated species, the spatial arrangement of patches (interpatch distances, contiguity, juxtaposition) can influence important processes such as predator-prey relationships by affecting refuge availability for prey and feeding efficiency for predators, and rate of movement between their habitats (Irlandi \& Crawford 1997, Micheli \& Peterson 1999, Grober-Dunsmore et al. 2007). Also, a seascape that is functionally connected for one organism may be disconnected for another because of individual or species-specific differences in physiological, anatomical, behavioral, life-history, and other ecological characteristics; thus, landscape corridors can be viewed as barriers to or paths of movement, depending on the fauna or process of interest. Direct quantitative estimates of actual ecosystem connectivity are still rare (Gillanders et al. 2003, Grober-Dunsmore et al. 2009), but are needed for the ecologically meaningful design and management of coastal reserves (Crowder \& Norse 2008, Palumbi et al. 2009). Thus, it is important to synthesize the wide range of individualistic responses by fauna to seascape structure in order to determine whether generalities exist and why similar responses may occur across taxa and functional groups. Landscape ecology holds great promise to increase our understanding of pattern-pattern and pattern-process 
relationships in ecology, as it provides an appropriate conceptual and analytical framework to quantify, analyze, and interpret spatial information on seascape structure, function, and change across multiple spatial scales.

The purpose of this paper is to review landscape ecology applications in coastal ecosystems. As seascape ecology encompasses many different research approaches and ecosystems (Hinchey et al. 2008 and this Theme Section), we focus here mainly on a subset that encompasses some of the most frequently studied structural attributes of patches and seascapes, including fragmentation, patch size, patch shape, and patch edge effects on faunal communities, in 5 key habitats: seagrass meadows, salt marshes, coral reefs, mangrove forests, and oyster reefs. In order to evaluate the generality in organism-seascape relationships across species, habitats, and ecoregions, we address the following 5 questions: (1) How has landscape ecology been applied to study relationships between individual organisms or ecosystem processes and seascapes? (2) Which attributes of seascape structure and response variables have been studied? (3) Are faunal response patterns and biological processes in changing seascapes linear, or do nonlinearities and critical thresholds exist? (4) What are the advantages of a seascape ecology approach, and what are the implications for coastal management including restoration efforts, MPA management, and spatial planning? (5) What are the key future research priorities for seascape ecology in coastal ecosystems?

\section{MATERIALS AND METHODS}

We used personal libraries and citations in literature reviews (Boström et al. 2006a, Connolly \& Hindell 2006, Grober-Dunsmore et al. 2009) to identify peerreviewed articles on landscape ecology applications to the study of coastal biogenic habitats. In most cases, we focused on the effect of spatial patterning for individual focal habitats, rather than the influence of the surrounding seascape context, primarily because the majority of studies had taken a single focal patch approach. However, we recognize that there are several notable exceptions (e.g. studies in which a multiscale, patch mosaic approach was applied). Our main inclusion criterion was that the study must contain a quantitative measure of one or several patch/landscape metrics (e.g. patch area, edge length, patch richness, nearest neighbor distance) that was then linked to a faunal response (e.g. variation in density, diversity, secondary production). Faunal groups included benthic invertebrates, fishes, and birds. Floral responses and abiotic patterns and processes (e.g. sediment dynam- ics, hydrodynamics) that interact with seascapes were outside the scope of this review. Mapping and modeling surveys using aerial photographs and geographic information systems to analyze patterns and dynamics in coastal ecosystems were not included unless patterns were quantitatively linked to a faunal response variable. Experiments in mesocosms were also excluded, but in situ manipulations of spatial structure using artificial seagrass units or artificial reefs were included. The connectivity literature relevant to coral reef ecosystems reviewed by Grober-Dunsmore et al. (2009) was also excluded. Complementary database searches using ISI Web of Knowledge (http://apps.isiknowledge.com) were conducted for the time period 1978 (earliest relevant study found) to June 2010 by entering partial words using wildcards (e.g. mangrove*, ${ }^{*}$ coral $^{*}$ ) combined with the following key words; landscape ecology, seascape, fragmentation, patch, and edge. The search included title, abstract, and key word within a record. To avoid redundancy with previous reviews, particularly with the seagrass literature, which was thoroughly reviewed through 2004 (Boström et al. 2006a, Connolly \& Hindell 2006), we searched primarily for seagrass seascape publications for the period 2004 to 2010. The total seagrass seascape literature (59 publications) allowed for a more detailed analysis of the generality of organism responses to patch size and edge effects than any other ecosystem. Both, seagrass and artificial seagrass studies were included. Following Connolly \& Hindell (2006), we classified individual faunal responses (usually differences in density or richness) as a significant positive effect, significant negative effect, or no effect. For example, a positive effect was recorded for species/taxa exhibiting a statistically significant increase in abundance with increasing patch size, or significantly higher abundance at the edge than in the interior of seagrass patches. Individual species scores and results for the same species/taxa at different sampling periods within a single study were treated separately.

\section{RESULTS}

\section{Application of landscape ecology in studies of organism-seascape relationships}

We included a total of 118 papers spanning the time period 1978 to 2010 and covering 17 countries (Appendix 1). The literature survey indicates a cumulative increase, but very little growth in the rate of applying landscape ecology to coastal environments (Fig. 2). Over that time span, there has been a steady average output of $\sim 5$ papers $\mathrm{yr}^{-1}$, often emerging from thesis research. Few research institutions include seascape 


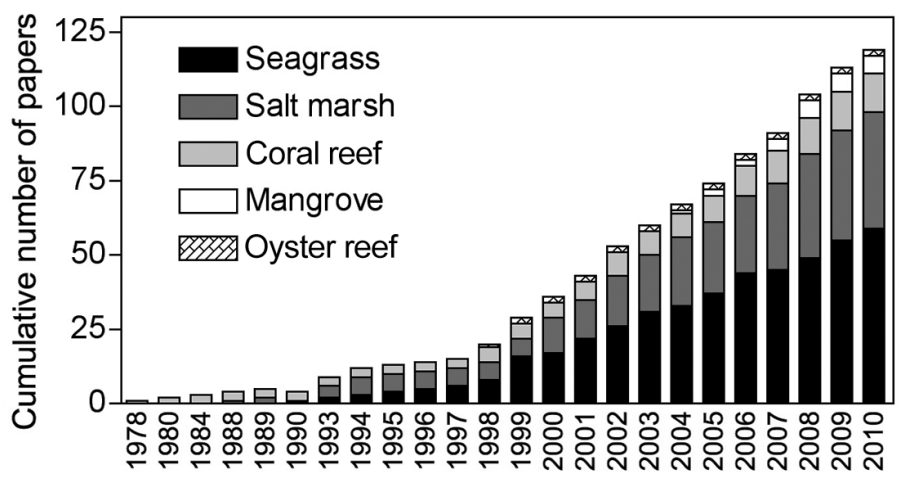

Fig. 2. Cumulative number of studies in coastal biogenic ecosystems applying landscape ecological principles to explain faunal responses

ecology as a primary focal area. Our understanding of seascape ecology is largely based on studies carried out in seagrasses (49\% of total number of studies) and salt marshes (32\%), while far fewer studies have been conducted in coral reefs $(11 \%)$, mangroves $(6 \%)$, and oyster reefs $(2 \%)$. There is also a considerable geographic bias in the studies, with most carried out in the USA and Australia (Fig. 3a). This is particularly evident in the seagrass and salt marsh literature. Seagrass ecosystems from regions such as the Caribbean, Indonesia, Africa, and Europe were under-represented in our survey, which limited our ability to generalize results across species and ecoregions.

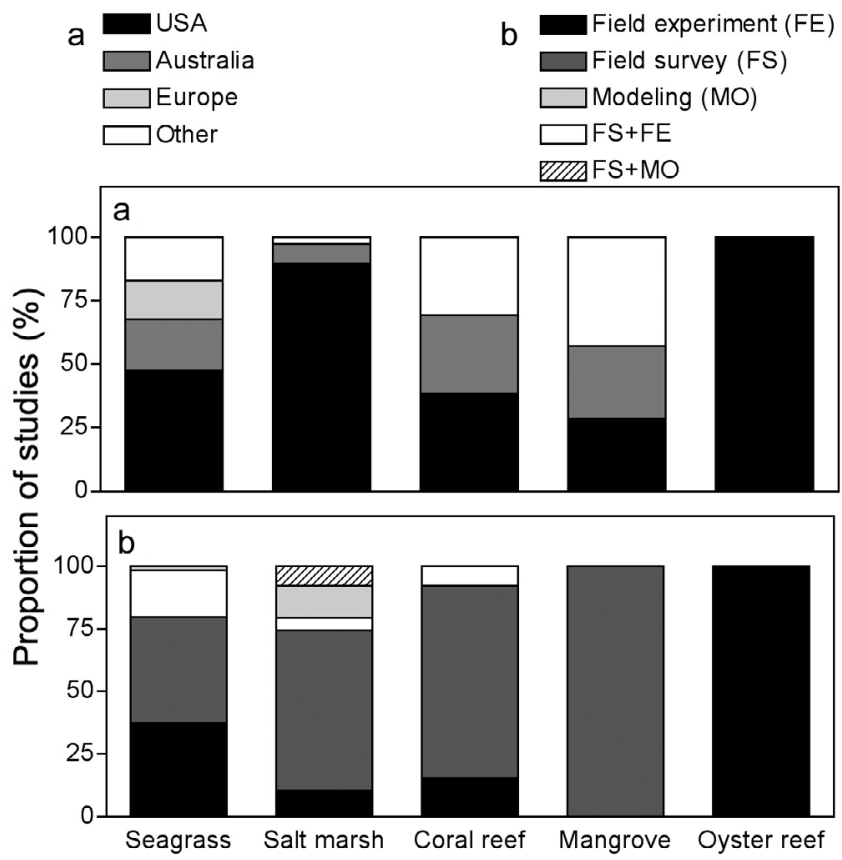

Fig. 3. (a) Geographical regions and (b) methodological approaches covered in the seascape literature (1978-2010, Appendix 1) linking seascape metrics to faunal response variables
The majority (60 to $90 \%$ ) of the studies within each biogenic system took a binary patch matrix approach (focal versus non-focal habitat) and focused on the faunal response to individual patch attributes (e.g. edge, size, perimeter:area ratio), while fewer ( 7 to $40 \%$ ) studied organism responses from a patch-mosaic perspective. In terms of methods, the seagrass publications indicate about equal contribution of descriptive and experimental approaches (often using artificial seagrass units; Appendix 1), and to some extent (18\%) a combination of both approaches, while manipulative field studies in marsh, mangrove, and coral reef habitats are still scarce (Fig. 3b). Very few oyster reef studies applied landscape concepts (Eggleston et al. 1998, 1999), even though landscape ecology was suggested to provide a useful conceptual framework to understand oyster reef ecology and restoration (Eggleston 1999). Several studies have quantified mosaics of multiple patch types across a range of spatial scales, although in most cases the seascapes were linked to faunal communities sampled in a single focal patch type (coral reefs, mangroves). Exceptions include a study that developed predictive maps of fish species richness across the seascape by integrating fish survey data collected in multiple patch types with benthic maps (patch mosaics) and surface complexity from bathymetry (continuous gradients) (Pittman et al. 2007). Very few studies have directly quantified seascape connectivity, although it is increasingly acknowledged as an important process in coastal ecology and for the design of effective management strategies (Gillanders et al. 2003, Mumby et al. 2004, Ray 2005, Weinstein et al. 2005, Meynecke et al. 2008, Grober-Dunsmore et al. 2009).

\section{Spatial and temporal scaling in seascape studies}

\section{Spatial scales}

The perception of seascapes varies greatly depending on site, organism characteristics (e.g. size, life stage, mobility), or the process of interest; therefore, no single spatial (grain and extent) or temporal (duration, temporal replication) scale for seascape studies can be defined (Wiens \& Milne 1989, Doak et al. 1992). Typically, scale selection is based on arbitrary choices, convention, or the type of question being addressed. The ecological rationale for scale selection is usually underdeveloped and unreported (Meentemeyer 1989, Pittman \& McAlpine 2003). In the studies reviewed, the spatial extent ranged from $100 \mathrm{~m}^{2}$ to $2000 \mathrm{~km}^{2}$, with seagrass, marshes, and coral seascapes representing the systems that were studied on multiple spatial scales. Direct comparisons of the spatial extent of sur- 
veys are problematic because the term 'site' may range from 1 to $400 \mathrm{~km}^{2}$, and refer to sampling locations within seascapes or to geographically (latitudinally) separated locations 100 to 1000s of km apart. Rarely are spatial scales aligned with specific ecological processes, such as a species home range area (but see Hitt et al. 2011, this Theme Section).

Unsubstantiated relative terminology such as 'small' and 'large' can also be misleading. For instance, in geography, a large-scale map is one of higher spatial resolution than a small-scale map. To avoid confusion, we advocate the use of 'fine-scale' and 'broad-scale' as relative terms, instead of 'large' and 'small' to be consistent with convention in landscape ecology. Quantitative estimates of actual spatial scales will avoid ambiguity. Not surprisingly, our review found that the definition of small (S), medium (M), and large (L) patches in seascapes ranged markedly across habitats, studies, and target species. For example, the following patch sizes were noted in seagrass studies of infauna: $\mathrm{S}=17-37, \mathrm{M}=41-72, \mathrm{~L}=82-147 \mathrm{~cm}$ in diameter (Hirst \& Attrill 2008), epifauna: $\mathrm{S}=0.6-6, \mathrm{M}=6-30$, $\mathrm{L}=33-87 \mathrm{~m}^{2}$ (Tanner 2006), fish: $\mathrm{S}=980-2300, \mathrm{M}=$ 3375-4090, L = 5335-6630 $\mathrm{m}^{2}$ (Jelbart et al. 2007). Likewise, the terms 'seascape scale' and 'seascape level' are uninformative and ambiguous and should not be used (Allen 1998, King 2005). In salt marshes, Kneib (1994) generally defined questions addressing fish feeding ecology at $\mathrm{S}=0.1-1, \mathrm{M}=10-100$, and $\mathrm{L}>$ $1000 \mathrm{~m}$ scales. Relative patch sizes for other marsh fish and benthic invertebrate studies have varied considerably: $\mathrm{S}<3000, \mathrm{~L}=4000-80000 \mathrm{~m}^{2}$ (Guest \& Connolly 2006), $\mathrm{S}=70-240, \mathrm{~L}=822-4347 \mathrm{~m}^{2}$ (Long \& Burke 2007), and $S=<1250, M=49000-96100, L>441500$ $\mathrm{m}^{2}$ (Rozas \& Minello 2010). In contrast, investigations of fish in patch reefs report remarkably similar patch size ranges: $2.5-60 \mathrm{~m}^{2}$ (Molles 1978), 0.3-60 $\mathrm{m}^{2}$ (Ault \& Johnson 1998a,b), and 0.6-64 m² (Chittaro 2002). Maximum spatial scales of coral reefs typically span 700 to $2300 \mathrm{~m}^{2}$ (Acosta \& Robertson 2002) or may exceed 15 ha (Grober-Dunsmore et al. 2008). The spatial scale of experimental oyster reef work typically has been restricted to 0.25 to $5 \mathrm{~m}^{2}$ patches (Eggleston et al. 1998, 1999).

\section{Temporal scales}

Biogenic habitats are temporally dynamic, often characterized by rapidly changing patch composition and spatial configuration due to disturbance events such as storms and freshwater flows (Santos et al. 2011, this Theme Section), high interannual fluctuations in recruitment, and seasonal changes in species abundance (Bologna \& Heck 2000, Shervette \& Gelwick
2008). Temporal variability has often been addressed by repeated sampling events ranging from hours (Darcy \& Eggleston 2005, Jackson et al. 2006b), months (Acosta \& Robertson 2002, Smith et al. 2010), to several years (Webb \& Kneib 2002, Gorman et al. 2009). When time has explicitly been incorporated as an explanatory variable, usually strong interactions have been found between spatial pattern metrics and time (Hovel \& Lipcius 2001, Johnson \& Heck 2006). For instance, edge effects in seagrasses may show inconsistent patterns among months (Fonseca et al. 1990, Horinouchi 2009), and strong diurnal variation of fish abundance may break down associations between fish and seagrass seascape configuration (Jackson et al. 2006a). In addition, inconsistent effects of seascape configuration demonstrated by interactions between time and patch size appear to be common across species (fish and decapods) and habitats (seagrass meadows, oyster reefs, and coral reefs) (Molles 1978, Eggleston et al. 1998, Jelbart et al. 2006, Johnson \& Heck 2006).

\section{Spatial pattern metrics and faunal response variables}

\section{Summary of trends across ecosystems}

The most commonly used spatial pattern metrics and target taxa in the 5 habitats examined are summarized in Fig. 4. The 5 most frequently applied landscape attributes and spatial phenomena in seagrass and salt marsh studies are spatial configuration (e.g. number of patches, total edge, mean fractal dimension), patch size, patch shape, edge effects, and percentage cover. Key target faunal groups studied in seagrass meadows and salt marshes included fishes, decapods, and motile epifauna. Twelve distinct faunal response variables were identified, but there appeared to be no trend in regard to which variables were used to measure responses across the 5 ecosystems (Fig. 5). The majority of response variables were measured with short duration 'snap shot' faunal surveys, often with no spatial or temporal replication and sometimes limited to a single season. The most common faunal community variables studied in seagrasses were the number of individuals and number of species, while salt marsh studies have emphasized production-related variables such as biomass, body size, and growth. Few studies have directly linked salt marsh spatial configuration to nekton diversity or infaunal species diversity (Kneib 1997). The emphasis in coral reef studies has been on determining the influence of patch size, habitat configuration, and more recently surrounding seascape composition on fish density and species richness (Fig. 4c,h), while the potential influence of coral reef configuration on invertebrates has rarely been addressed. Increasing aware- 


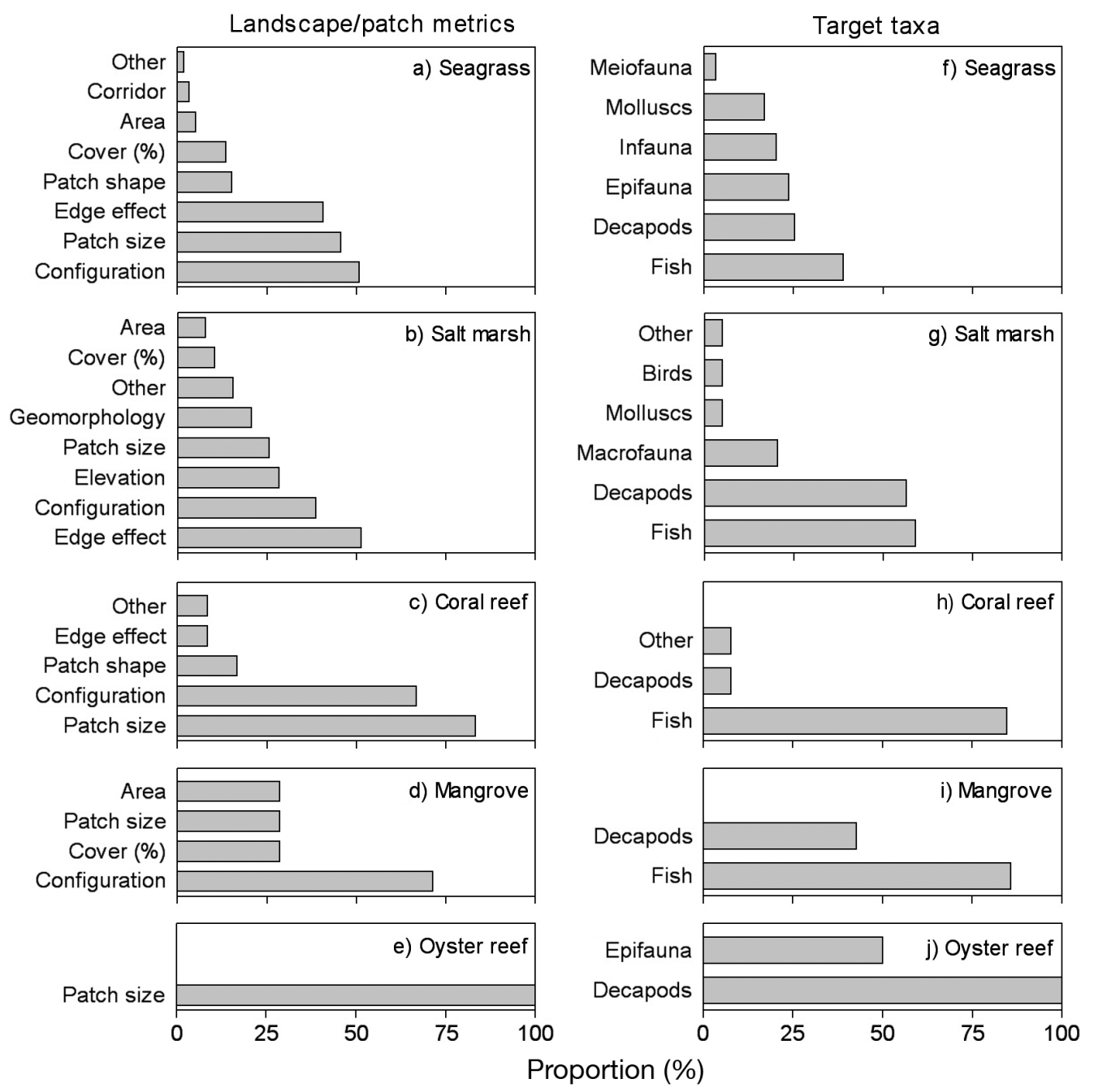

Fig. 4. Summary of (a-e) spatial pattern metrics applied to explain (f-j) target faunal groups in the 5 biogenic ecosystems studied. Patch size includes studies reporting habitat area measurements. Configuration refers to various landscape indices used to quantify the component habitat, e.g. number of patches, total edge, mean fractal dimension, total core area, contagion. Detailed descriptions of these metrics provided by McGarigal \& Marks (1994). For salt marshes (b), geomorphology refers to channel network complexity (width, length, order, slope), and elevation to e.g. inundation regime, water depth, and edge elevation. Decapods refer almost exclusively to shrimps/prawns and crabs, while epifauna, macrofauna, and infauna refer to sampling of whole invertebrate assemblages

ness of the multi-habitat movements of many common fish in coral reefs has resulted in a shift toward patchmosaic studies that quantify seascape composition and, in fewer cases, the geometric properties of seascape configuration (Kendall et al. 2011, this Theme Section). Our understanding of the causes and ecological consequences of structural patterns in oyster reefs and influence on associated fauna is restricted mainly to studies of patch size effects on macrofauna and decapods (Fig. 4d,i) and requires more focus. Despite the importance of mangroves for coastal and offshore fisheries (Faunce \& Serafy 2006) and the loss of mangroves globally, effects of mangrove seascape configuration and mangrove patch size have only been addressed in a handful of studies, with the majority focusing on fish (Fig. 4e,j).

\section{Patch size effects}

Seagrass meadows. Fish and invertebrate responses to differences in seagrass patch size were very consistent in the seagrass literature. About $70 \%$ of invertebrate and $75 \%$ of fish responses to patch size were not statistically significant (Fig. 6a,b). This suggests that fish and invertebrates are insensitive to changes in patch size at the spatial scales represented in the published literature. A major caveat here is that these results are probably de- 


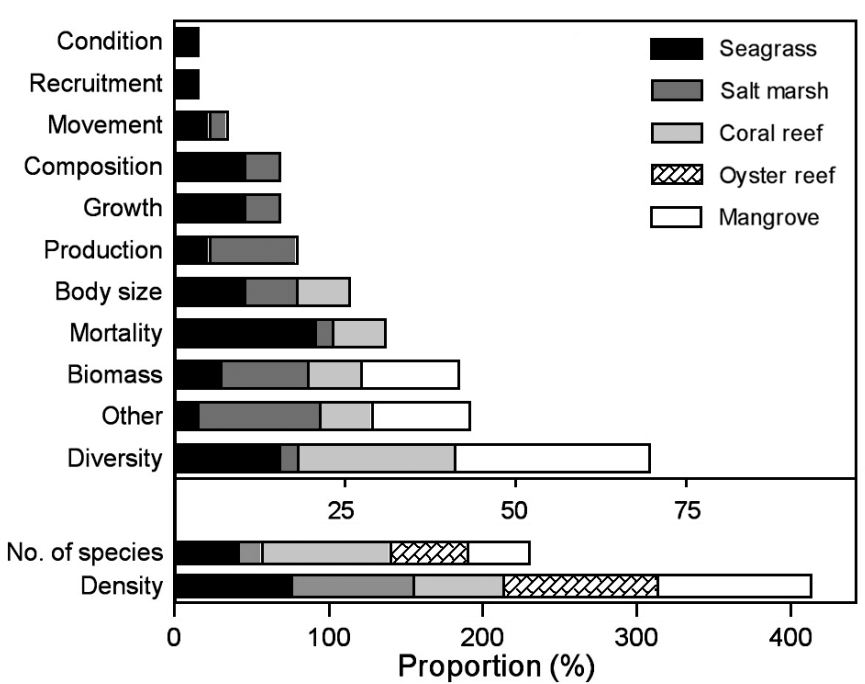

Fig. 5. Faunal response variables measured to investigate the influence of landscape or patch features on the 5 biogenic ecosystems. Density: number of individuals or abundance. No. of species: number of taxa or species recorded. Diversity: calculated diversity indices for faunal assemblages, e.g. Shannon-Wiener H', Simpson Index (Jackson et al. 2006b, Reed \& Hovel 2006). Production: animal secondary production, see e.g. Minello et al. (2008). Mortality incorporates studies reporting prey survival and predation pressure in relation to spatial pattern metrics. Biomass: a static measurement of the amount of animal biomass reported as dry or wet weight. Other: more rarely reported response variables such as number of functional groups, catch per unit effort, or cohort size. Movement: animal movement ranges measured in situ (Pittman et al. 2007) or estimated using simulation models (Haas et al. 2004). Composition: studies investigating influence of spatial configuration on the composition of infaunal or epifaunal assemblages using multivariate statistics (e.g. Frost et al. 1999, Tanner 2003, Mills \& Berkenbusch 2009)

pendent on arbitrarily defined differences between small versus large patches, rather than ecological processes (see 'Results - Spatial and temporal scaling in seascape studies'). The relative portions of significantly positive (increasing fish density or richness with increasing patch size) and negative (decreasing fish density with increasing patch size) responses were 10 and $20 \%$, respectively. The partly dissimilar corresponding scores for invertebrate responses (17\% positive and $7 \%$ negative) suggest that overall invertebrate density and richness are more likely to increase than decrease with increasing patch size. When scores were pooled for all fauna, the proportions for no response, positive response, and negative response were 76, 17, and 7\%, respectively (Fig. 6c). Patch size effects on infauna are still understudied. Hirst \& Attrill (2008) found no impact of the size range 17 to $147 \mathrm{~cm}$ in diameter on infaunal abundance and diversity, suggesting that even very small patches have high faunal diversity and abundance, and thus may have high conservation value. In another study from the UK, Bowden et al. (2001) sampled small (diameter $<15 \mathrm{~m}$ ) and large (diam-
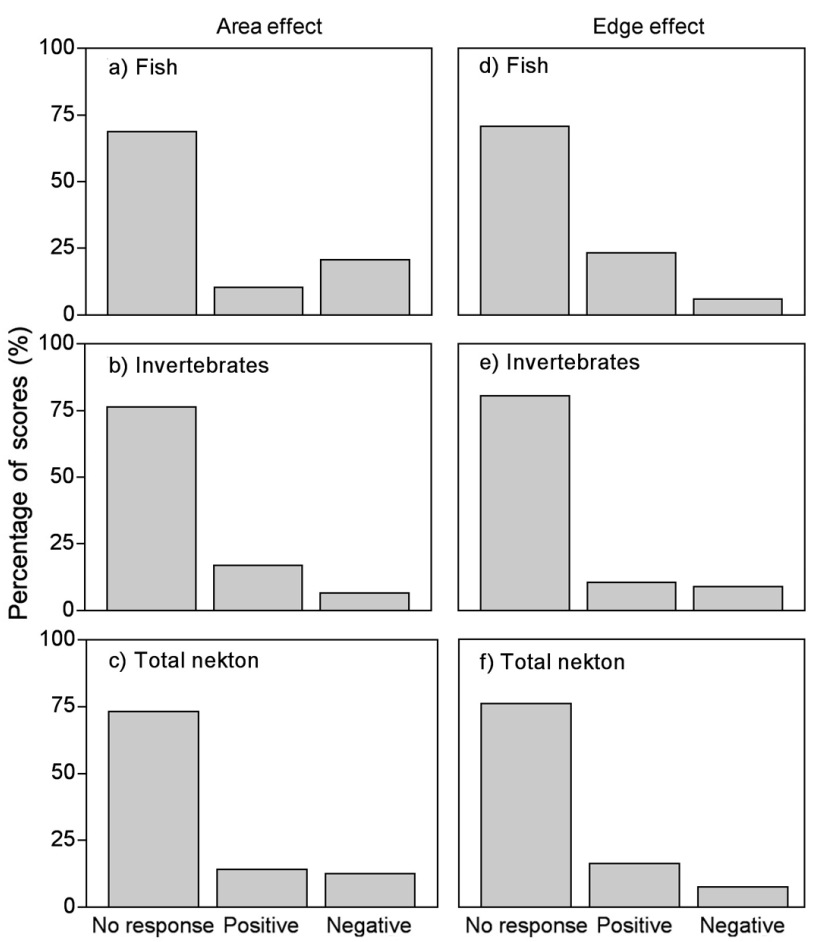

Fig. 6. Summary of $(\mathrm{a}, \mathrm{d})$ fish and $(\mathrm{b}, \mathrm{e})$ invertebrate as well as $(\mathrm{c}, \mathrm{f})$ total nekton responses to area (patch size) and edge effects (edge-interior comparisons) in seagrass seascapes. Only statistically significant responses in species density or richness are included. For details, see 'Materials and methods' and Connolly \& Hindell (2006). Area effects are based on the following studies: Bell \& Westoby (1986), McNeill \& Fairweather (1993), Eggleston et al. (1998, 1999), Bell et al. (2001, 2002), Hovel \& Lipcius (2001), Laurel et al. (2003), Tanner (2006), Jelbart et al. (2006, 2007), Johnson \& Heck (2006), Hirst \& Attrill (2008), and Mills \& Berkenbusch (2009). Edge responses are based on results reported by Fonseca et al. (1990), Bologna \& Heck (2002), Hovel \& Lipcius (2002), Hovel et al. (2002), Sánchez-Jerez et al. (1999), Uhrin \& Holmquist (2003), Tanner (2006), Jelbart et al. (2006), Smith et al. (2008), Horinouchi (2009), Macreadie et al. (2010), Smith et al. (2010), and Vonk et al. (2010)

eter $>30 \mathrm{~m}$ ) Zostera marina patches and found a higher number of infaunal taxa, but not higher density and diversity $\left(H^{\prime}\right)$, in large patches compared to small.

Salt marshes. A few investigations of patterns in more mobile macroinvertebrates such as crabs have reported marsh patch size effects. In Chesapeake Bay (USA), Long \& Burke (2007) found higher densities of fiddler crabs (Uca spp.) in a large (800-4300 $\left.\mathrm{m}^{2}\right)$ marsh than in a small (60-240 $\left.\mathrm{m}^{2}\right)$ marsh, but did not explicitly test patch size effects. As an indirect indication of patch effects on crabs, Guest \& Connolly (2006) found that carbon flows supporting the red-handed shore crab Parasesarma erythrodactyla were higher in large (0.4-8.1 ha) than in smaller (<0.3 ha) mangrove/marsh (Avicennia marina, Sporobolus virginica) patches. Although there is considerable descriptive information 
on nekton composition and abundance relative to total marsh area, few studies have related nekton density to individual patch size or density, and the documented relationships vary considerably by species. Meynecke et al. (2008) provided one of the few comparisons of fish biomass by patch size across a comprehensive seascape mosaic composed of seagrass, mangrove, marsh, other wetlands, mud, and sand patches (Queensland, Australia). In 1 of their 2 study regions, they found that fish catch was best explained by marsh and wetland patch density. Meyer \& Posey (2009) described similar findings from North Carolina (USA) marshes, where the resident mummichog (killifish) Fundulus heteroclitus was found exclusively in the marsh and at greater densities in continuous marsh vegetation than in isolated patches, while the co-occurring transient pinfish Lagodon rhomboides was found in both the marsh plain and adjacent tidal flats. The abundance and productivity of avifauna has also been correlated to marsh size and patch density, but the relative importance varied with scale and surrounding land use. Landscape context was found to be particularly important for birds visiting New England marshes, where Shriver et al. (2004) found species richness to be $20 \%$ higher in larger marsh patches, but the effects of road density and marsh isolation varied according to the level of surrounding development. Spautz et al. (2006) found that each of 4 bird species in San Francisco Bay, California (USA), showed affinity for specific marsh plants and vegetative structure, but marsh size and adjacent development were also important predictors of abundance, while effects of finer-resolution spatial pattern metrics were insignificant for birds responding to the marsh and ecotone mosaic across 0.5 to $2 \mathrm{~km}$.

Coral reefs. Sale \& Douglas (1984) sampled fish communities on 20 coral patch reefs of varying surface area ( 2.71 to $28.35 \mathrm{~m}^{2}$ ) on the Great Barrier Reef and found significant positive correlation $(r=0.67)$ with species richness. Similarly, in the US Virgin Islands, GroberDunsmore et al. (2007) found that coral reef patch size was significantly correlated with fish species richness ( $r=0.43, \mathrm{p}<0.001$ ), and Chittaro (2002) found a significant positive species-area relationship, where area explained 66 to $96 \%$ of the variation in species richness. This relationship appeared to be scale dependent, because at finer spatial scales $\left(0.6\right.$ to $\left.64 \mathrm{~m}^{2}\right)$, patch reefs contained $35 \%$ more species than contiguous coral reefs, while at broader spatial scales (100 to $200 \mathrm{~m}^{2}$ ), the number of species on contiguous coral reefs was similar to that of patch reefs (Chittaro 2002). Overall, other habitat characteristics also played a role, and contiguous coral reefs with greater habitat richness contained more fish species per area than less habitat-rich patch reefs of equal size. To determine whether a single large patch supported more fish than several small patches (the so called 'single large or several small' [SLoSS] debate, see also McNeill \& Fairweather 1993 for an analogous seagrass study), Acosta \& Robertson (2002) surveyed fish on coral reefs in Belize and found greater abundance on relatively large $\left(\right.$ mean $\left.=2300 \mathrm{~m}^{2}\right)$ coral reefs than on a cluster of 3 small (mean $=740 \mathrm{~m}^{2}$ ) patch reefs. However, results for species richness from rarefaction analyses indicated that both species richness and species evenness were similar between a single large coral reef and 3 smaller reefs of equivalent total area.

Mangroves. In Australia, the proportion of mangroves in the seascape was only weakly positively correlated with the density of fish assemblages sampled in mangroves, but made a significant contribution to explaining fish species richness (Pittman et al. 2004). In Florida, mangrove area was a significant predictor in only 2 of 15 fish-seascape models, where it was negatively correlated with the density of juvenile barracuda Sphyraena barracuda and total fish density (Drew \& Eggleston 2008). The perimeter:area ratio of mangrove islands, however, was a significant predictor of juvenile gray snapper Lutjanus griseus abundance. Halpern (2004) measured the amount of mangroves and their proximity to coral reefs in the Virgin Islands and found no relationship between the density of adult schoolmaster snapper L. apodus on coral reefs, but he found a significant relationship for the yellow-fin morjarra Gerres cinereus when data where pooled for entire islands. In the Philippines, a weak positive correlation was found between mangrove area and the catch of 4 families of commercial fish (Paw \& Chua 1991).

Oyster reefs. In intertidal and subtidal areas, oyster reefs form landscape mosaics with patches ranging in size from single shells to kilometer-wide reefs (see Eggleston 1999 for a synthesis) (Fig. 1). Eggleston et al. (1998) revealed evidence of decreasing shrimp densities with increasing oyster patch size $\left(0.25\right.$ to $\left.4.0 \mathrm{~m}^{2}\right)$, while the first benthic stages of blue crabs showed opposite patterns. In addition, Eggleston et al. (1999) reported significantly fewer large macrofauna species in small $\left(0.25 \mathrm{~m}^{2}\right)$ oyster shell patches compared to mixed patches (oyster shell and seagrass) and seagrass patches of the same size. In terms of small macrofauna, large $\left(1 \mathrm{~m}^{2}\right)$ oyster shell patches supported more species than seagrass and mixed patches of the same area.

\section{Edge effects}

Seagrass meadows. Although the seagrass-sand boundary represents a zone with abrupt transitions in many environmental and biological variables, most $(75 \%)$ faunal taxa showed no significant edge responses (Fig. 6d-f). Fishes, however, showed proportionally more ( $25 \%$ of scores) positive edge effects (i.e. 
higher abundance and/or richness) than invertebrates (10\% of scores). Fewer data are available on infaunal responses to seagrass patch edges, but the density of polychaetes has been shown to peak at patch edges in different regions and seagrass landscapes (UK: Bowden et al. 2001; Australia: Tanner 2005; USA: Bologna \& Heck 2002), although opposite patterns (i.e. interior aggregations) have also been observed (Bell et al. 2001).

Salt marshes. Almost half of the published marsh studies we reviewed reported faunal responses to patch and corridor edges. Descriptive studies have usually adopted 1 of 2 approaches: (1) sampling along gradients across edges, or (2) comparing different landscapes with varying amounts of edge $\mathrm{km}^{-2}$ (edge density). Browder et al. (1989) modeled shrimp abundance in Louisiana (USA) and found a strong positive relationship between brown shrimp Farfantepenaeus aztecus catch and the total length of marsh edge, and a relationship between wetland loss (manifested as fragmentation) and the amount of marsh edge. Subsequent empirical and modeling studies of faunal density along vegetated marsh edges compared to interior marsh and mudflat (matrix) areas also demonstrated consistent evidence of greater fish and shrimp concentrations within 1.25 to $3 \mathrm{~m}$ of the marsh edge (Baltz et al. 1993, Minello et al. 1994, Peterson \& Turner 1994, Cicchetti \& Diaz 2000, West \& Zedler 2000, Minello \& Rozas 2002, Haas et al. 2004, Roth et al. 2008). However, most of these studies were conducted in the northern Gulf of Mexico. On the US Atlantic coast, Kneib (2003) demonstrated a positive relationship between nekton production and edge density within a 200 m radius of sampling locations on the interior intertidal marsh plain. Webb \& Kneib (2002) also identified a relationship between the amount of intertidal marsh edge and the abundance of white shrimp Litopenaeus setiferus in adjacent subtidal channels of Georgia (USA) salt marshes. An investigation of the fine-scale distribution of benthic infauna relative to edge in a Gulf of Mexico marsh indicated that infauna were negatively related to the distance from the marsh edge, with the greatest densities occurring during winter and early spring when predator abundance was low (Whaley \& Minello 2002). However, this pattern is not consistent across taxa or regions. For example, Kneib (1984) reported a variety of intertidal distribution patterns for different taxa of benthic invertebrates with distance from the marsh edge on Sapelo Island, Georgia (USA). On the US Atlantic coast, preferred epibenthic crustacean prey (e.g. tanaids and talitrid amphipods) of marsh nekton often tend to be more abundant at greater distances from the edge into the interior of the marsh plain (Kneib 1992, Covi \& Kneib 1995). Lewis \& Eby (2002) investigated the spatial patterns of gastropods (periwinkle snails) and blue crab, their predators, along the edge of a North Carolina (USA) Spartina alterniflora marsh and found that pursuant to the concept of increased inhibition of crab foraging with increasing distances into dense $S$. alterniflora marsh, snail densities increased positively with increased distance from the marsh edge. Although responses were found to be highly taxa specific, Fleeger et al. (2008) also found that marsh edge (as well as adjacent tidal channel wall) exhibited the strongest response by invertebrates to experimental predator removal and nutrient additions.

Coral reefs. Acosta \& Robertson (2002) found 30\% more edge-habitat fish species on small $\left(700 \mathrm{~m}^{2}\right)$ reefs exhibiting a higher perimeter:area ratio than large $\left(2300 \mathrm{~m}^{2}\right)$ reef patches, and fish species composition was markedly different when comparing the bottom edges of patch reefs with the reef top. Vanderklift et al. (2007) examined fish communities at varying distances (0 to $1100 \mathrm{~m}$ ) from rocky reefs in Western Australia and observed an abrupt decline of small predatory fish within the first $30 \mathrm{~m}$ from the reef, indicative of a negative edge effect. Similarly, Dorenbosch et al. (2005) in the western Indian Ocean observed an edge effect for coral reef-associated species and generalist species, where fish densities and species richness decreased significantly within $30 \mathrm{~m}$ of the patch reef boundary.

\section{Fragmentation effects}

Seagrass meadows. Because fragmentation is a dynamic process, not a state, there is a need to distinguish the static, postfragmented state or habitat patchiness from active habitat fragmentation. In the majority of studies examined here, fragmentation was approached by studying the static arrangement of different-sized natural and artificial patches, or by making comparisons between continuous and patchy configurations considered to represent different levels of fragmentation (e.g. Mizerek et al. 2011, this Theme Section). However, despite the prevalence of anthropogenic (propeller scarring, anchoring, dredging, trawling) and non-anthropogenic (storms) disturbances, there have been few attempts to conduct natural experiments or to experimentally fragment habitat and measure immediate responses (but see Reed \& Hovel 2006, Macreadie et al. 2009). In a novel experimental design comparing patchiness with active fragmentation, Macreadie et al. (2009) found higher fish densities in actively fragmented treatments compared with nonfragmented controls, and more species in actively divided patches compared to a static arrangement of patches of the same total area. These results are among the first to indicate that fragmentation is not analogous to patchiness, and that fragmentation 
effects might be compensated by edge effects and crowding, especially in fish assemblages dominated by habitat specialists (e.g. pipefish). When comparing continuous ( $>2$ ha) and fragmented seagrass (patch size range: 6 to $9 \mathrm{~m}^{2}$ ), Frost et al. (1999) found no effect of seascape configuration on infaunal density, diversity (19 taxa, $H^{\prime}=2.40$ to 2.49 ), silt content and rhizome biomass, but configuration had a significant influence on the composition of the infaunal community. Similarly, in a comparison of fragmented (patch size range: 1 to $200 \mathrm{~m}^{2}$ ) and continuous meadows $\left(>1000 \mathrm{~m}^{2}\right)$ in 2 intertidal inlets in New Zealand, Mills \& Berkenbusch (2009) found significant effects of seascape configuration on infaunal community composition. In the same study, density of individuals and the number of taxa (range 48 to 52) was significantly lower in fragmented landscapes at both study sites, while diversity $\left(H^{\prime}=\right.$ 1.8 to 2) showed inconsistent patterns in relation to configuration between sites. In the Gulf of Mexico (USA) Rakocinski et al. (2008) contrasted an exposed, fragmented (mean cover: $12 \%$, mean patch size: $85 \mathrm{~m}^{2}$ ) and a sheltered, less fragmented (mean cover: $45 \%$, mean patch size: $645 \mathrm{~m}^{2}$ ) seagrass meadow and recorded $4 \times$ higher total invertebrate abundance and $10 \times$ higher gastropod densities in the less fragmented meadow, but no effects on species richness (86 taxa) and diversity $\left(H^{\prime}=2.3\right.$ to 2.8$)$. Interpretation of configuration effects is difficult due to confounding effects of wave exposure, and rarely have studies accounted for the interacting effects of hydrodynamics on faunal distributions (but see Turner et al. 1999).

Salt marshes. Few studies have tracked changes in ecological responses with the actual temporal fragmentation of marshes, while many have only assumed marsh structure indicative of slow disintegration (e.g. Minello \& Rozas 2002). Fragmentation or increase of non-vegetated matrices appears to result in mostly positive faunal responses until thresholds are reached. Browder et al. (1989) predicted increases for brown shrimp production until salt marsh fragmentation reached a threshold (60\% cover), after which shrimp production was expected to decline. Rozas et al. (2007) found that fish and decapod populations decreased by 34 to $95 \%$ over a 7 yr period during which $61 \%$ of a Texas (USA) marsh converted to open water. Much of this effect was likely manifested through a $71 \%$ decrease in marsh edge over that period.

Coral reefs. Few studies have addressed the influence of the spatial arrangement of coral reef patches across the seascape on faunal distributions, and therefore little is known about the potential impact of fragmentation. On the Great Barrier Reef, Australia, Ault \& Johnson (1998a) recorded higher species richness on the larger patchy coral reefs than contiguous coral reefs. Patch reef assemblages, however, were more dynamic in time and space. On contiguous coral reefs, fish assemblage composition was more predictable and was best explained by within-patch structural attributes such as benthic composition, depth, and topographic complexity. To examine the influence of patch isolation on fish assemblages, OverholtzerMcLeod (2006) constructed arrays of artificial patch reefs with different inter-patch distances (5 to $50 \mathrm{~m}$ ) in the Bahamas. The spatial configuration of patches influenced important predator-prey interactions affecting both the magnitude of total predation and the existence of density-dependent mortality for 2 common coral reef-associated species. Juvenile mortality rates for yellowhead wrasse Halichoeres garnoti and beaugregory damselfish Stegastes leucostictus were density dependent on reefs that were relatively isolated, but density independent on reefs that were more closely spaced. In the Pacific, Molles (1978) surveyed fish assemblages on rocky reefs of varying sizes $\left(2.5\right.$ to $\left.60 \mathrm{~m}^{2}\right)$ and found a significant negative correlation between reef isolation (6 to $60 \mathrm{~m}$ apart) and number of fish species, and a significant positive correlation with patch reef area.

Mangroves. We found only 1 study that explicitly quantified the spatial configuration of mangrove patches as a predictor of coastal faunal distributions. This study did not, however, track the process of fragmentation, but sampled mangroves varying in spatial configuration. For density of fish using mangroves at high tide, Pittman et al. (2004) found that mean nearest neighbor distance of mangroves was the most significant variable in explanatory models (path coefficient $[\mathrm{pc}]=0.59, t=2.19, \mathrm{p}<0.01$ ), although this appeared to influence species differently. Few species, however, preferred the more 'fragmented' patches, yet those that did were some of the most abundant schooling species in the samples and were well adapted to exist in open sandy areas.

\section{Effects of channel geomorphology and inundation regime in salt marsh seascapes}

The distribution and abundance of marsh fauna can often be explained by the geomorphic structure of channels (e.g. complexity, density, depth) because these are the primary corridors for movements into and out of marshes and adjoining ecotones for most mobile coastal fauna (Figs. $7 \& 4$ b). Furthermore, faunal responses to channel networks can be explained by both passive (tidal hydrology) and active (behavioral) selection processes. Desmond et al. (2000) found higher fish densities in 1st-order than in higher-order channels. Visintainer et al. (2006) also found that lower-order channels contained higher densities of small fish species, but species richness and densities of juveniles of 


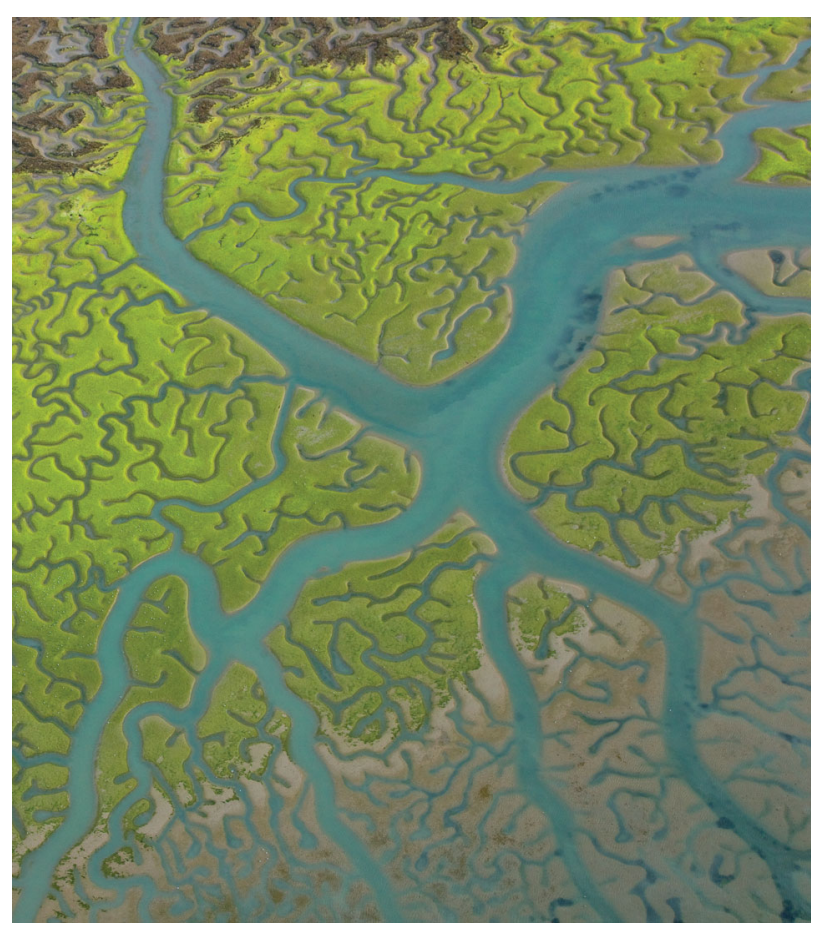

Fig. 7. Tidal marsh channel seascape in Cadiz Bay Natural Park, Spain. Photo: J. C. Muñoz

larger species were greater in higher-order (larger) channels. Tidal channel size rather than channel order may be a more important determinant of faunal assemblage structure; for instance, Rozas et al. (1988) found that the highest catch per unit effort (CPUE) of fishes accessing a Virginia (USA) marsh was found in the small 'rivulets' that dissected channel banks, where $41 \%$ of the fishes were captured even though the entrance to rivulets only accounted for $3 \%$ of the subtidal channel length. Similarly, Allen et al. (2007) suggested that although the highest nekton abundance and richness were found in shallow, broad tidal channels that filled/emptied slowly, differences in nekton abundance among channels ranged from $3 \times$ to $30 \times$ on the same day. There may actually be trade-offs between occupation of different tidal channel networks. Kneib (2009) found that mummichogs in Georgia (USA) Spartina alterniflora marshes were more dense in complex channel networks (headwaters) but that their field growth rates were greater in simple networks located closer to larger, open waters of the estuary. Similar responses might also be the case for subtidal populations of mysids (Neomysis kadiakensis), which Dean et al. (2005) found to incur significant adult mortality when imported into a San Francisco Bay, California (USA), marsh through a 4th-order tidal channel.

Tidal channel metrics have also been linked to trophic support of nekton in marsh-ecotone seascapes. Hood (2002a,b) illustrated how tidal channel allometry in Pacific Northwest tidal wetland complexes (emergent marsh, scrub-shrub, and forested wetland ecotone) related to the export probability of juvenile salmon prey (adult flies, aphids) as a function of channel size (perimeter, mouth area) and emergent marsh area. Larger and more complex channel networks that integrated emergent marsh with wetland ecotone had higher amounts of organic material in channel sediments and a greater abundance of benthic surface deposit feeders. At a finer scale, microtopographic patches and elevation zones in marsh plains can also provide sources and sinks of invertebrate fish prey as well as low-tide refugia for resident marsh nekton (Kneib 1994).

Hydroperiod is the ultimate control of access to the marsh and adjacent ecotones, and inundation frequency and duration may obscure effects of even large marsh edge or patch variability especially where meteorological effects drive microtidal regimes and marshes can experience extended periods of submergence (Rozas 1995, Kneib 1997). Many studies of nekton access to, and occupation of, marshes and ecotones relate nekton densities and production to inundation frequency and duration, arguing that nekton penetrating the marsh plain derive food and refuge from predation that is otherwise less available in lower tidal elevations (e.g. Rozas 1995). Rozas \& Reed (1993) found higher densities of penaeid shrimp in low Spartina alterniflora marshes than in medium Spartina or high Distichlis marshes even when all 3 were submerged, seemingly driven by inundation time and depth irrespective of marsh edge. Kneib (2000) compared the density of white shrimp Penaeus setiferus and mummichogs on the marsh at high and low intertidal elevations under a range of tidal inundation durations; results showed that distance from the marsh edge (elevation) was less important than inundation duration, especially for white shrimp. In a study that actually related flooding frequency and duration to marsh edge, West \& Zedler (2000) found that the southern California (USA) salt marsh edge, where they documented increased fish catches, was tidally inundated to a depth of at least $20 \mathrm{~cm}$ an average of $15.6 \%$ of the time compared to only $9.3 \%$ of the time on the adjacent marsh plain.

\section{Importance of patch context and connectivity in coral and mangrove ecosystems}

\section{Patch adjacency and proximity}

Multi-scale analysis of fish-seascape relationships by Grober-Dunsmore et al. (2007) demonstrated that the amount of seagrass surrounding coral reefs was positively correlated with fish density and species rich- 
ness. As much as 48 to $58 \%$ of the variation in fish assemblages on coral reefs was explained by the amount of seagrass in surrounding areas. In particular, the coral reefs with large amounts of seagrass in close proximity $(<100 \mathrm{~m})$ supported the highest abundance of grunts (Haemulidae) and snappers (Lutjanidae). The amount of seagrass within $100 \mathrm{~m}$ radius was the most significant spatial scale for explaining fish-seascape relationships in SW Puerto Rico (Pittman et al. 2007), Queensland, Australia (Pittman et al. 2004), and elsewhere (in the US Virgin Islands; Kendall et al. 2003). Further evidence for the importance of patch adjacencies comes from multi-habitat studies that have not taken a landscape ecology approach. In Belize, spiny lobsters, particularly juveniles, were significantly more abundant in mangroves and coral islands surrounded by seagrass (Acosta 1999), and the biomass of several fish species more than doubled where coral reefs existed in close proximity to extensive mangroves (i.e. $35 \%$ of coastline; Mumby et al. 2004).

\section{Structural and functional connectivity}

Limited evidence suggests that connectivity is likely to be as vital a seascape attribute in coastal ecosystems as it is in terrestrial ecosystems. Seascape connectivity is rarely studied as a spatially-explicit process linking benthic patterns to animal movements. Information on broad-scale movements across mosaics of patch types, however, suggests that seascape patterns will be an important variable for many benthic and demersal species that undertake diel migrations, ontogenetic shifts, and seasonal and spawning migrations between adjacent patches and across continental shelves (Kneib 2000, Pittman \& McAlpine 2003). In Queensland, Australia, Meynecke et al. (2008) found that structural connectivity of the seascape was the single most influential variable for fisheries. In particular, connectivity indices for mangroves, salt marsh and channels explained the largest proportion (30 to $70 \%$ ) of variability in fisheries catch, indicating that connected tidal wetlands are important for fisheries. The CPUE of a key species, barramundi Lates calcarifer, was best explained by the number of wetland patches, mangrove connectivity and wetland connectivity $\left(r^{2}=0.38, n=28\right)$.

Ecological thresholds in species-habitat relationships

We identified both, non-linear species responses and threshold levels in coverage in the seascape literature (Table 3). In general, fish and mobile epifauna appear to be robust to even extreme changes in seagrass cover (Pittman et al. 2004, Reed \& Hovel 2006). Three studies demonstrated a positive parabolic relationship between seagrass patchiness and fish abundance, suggesting that continuous vegetation cover and/or large patches may be suboptimal for many fish species (Salita et al. 2003, Gorman et al. 2009, Thistle et al. 2010). Similarly, nekton populations in salt marshes may benefit from early stages of fragmentation and show positive curvilinear relationships to increasing fragmentation, but populations decline at $\sim 60 \%$ (Browder et al. 1989) or $<30 \%$ marsh cover (Minello \& Rozas 2002, Haas et al. 2004). Species richness of coral reef fish may also show considerable declines when surrounding seagrass coverage drops below 30\% (Grober-Dunsmore et al. 2009), but threshold responses related to focal (coral) habitat configuration have not been demonstrated; however, see Pittman et al. (2009) for complexity related thresholds in coral reef ecosystems.

\section{DISCUSSION}

\section{Habitat fragmentation}

Fragmentation of habitat is an important driver of species loss and degradation of ecosystem functions in many terrestrial ecosystems (Didham 1997, Hanski 2005). The term 'habitat fragmentation,' however, remains conceptually ambiguous because it involves both reduction in area and change in configuration. Furthermore, many habitat fragmentation studies have not examined the phenomenon as a dynamic process, but instead have sampled patchy habitats, sometimes along a gradient. The use and application of the term is further complicated by our poor ability to discriminate between natural and human-induced changes in natural environments, and because organisms perceive patchiness in different or contradictory ways (Haila 2002). Our review of the coastal fragmentation literature provided no exception for several reasons. Firstly, the mechanisms causing fragmentation are widely different in different regions (Table 2). Secondly, there is a wide range in the spatial and temporal scales at which habitat fragmentation has been studied. Thirdly, organisms seem to respond to the process of fragmentation in different ways, and little direct evidence is available to assess behavioral responses. All of these factors make the study of coastal fragmentation very challenging and inhibit our ability to directly compare studies, identify general patterns, or predict consequences across systems, and ultimately design coastal reserves based on relevant information.

Habitat fragmentation is a complex process (not a state) seldom resulting in the mere splitting of habitat (sensu Fahrig 2003). Rather, in coastal (and terrestrial) systems, fragmentation typically involves multiple 
sampling of patchy natural systems address these issues and identify effects, emerging findings are usually confounded by habitat complexity combined with site and time-specific responses. Such methodological trade-offs suggest that complementary approaches using repeated, small-scale manipulations in combination with broad-scale interannual surveys would be more productive approaches to tackling complex animal-habitat relationships in seascapes.

\section{Edge effects}

Edge effects were originally defined by Odum (1958) as the tendency for increased population density and species richness at the junction between 2 communities. The boundaries or transition zones between patch types often exhibit abrupt changes in physical structure, community biomass, assemblage composition, and sometimes provide navigable pathways for migrations and sites for spawning (Johannes 1978). This is likely to occur because mixing of species from 2 adjacent patch types and preferential use of edges offers greater access to resources in multiple patches. However, the majority of studies (70 to $75 \%$ ) that have examined edge effects in coastal fishes and invertebrates have found no persistent response to edge (neutral edge response). Of the remainder, a positive response was found more often than a negative one, particularly for fish. In terrestrial avian literature, positive responses to edges are also more commonly found than negative edge responses (Sisk \& Battin 2002). Avoidance of edges is more likely to be a response of a habitat specialist adapted to patch interior conditions than a generalist using resources in multiple patch types. Furthermore, edges within a patch type can differ due to both the internal heterogeneity of the patch and the patterning of the surrounding seascape. In our synthesis, the majority of studies examined edge responses for patches of seagrasses. A stronger edge effect was evident for coral reefs, marshes, and mangroves than for seagrass meadows, which likely corresponded to a more distinctive contrast in structural complexity that characterizes the edge where it adjoins lower-complexity soft sediments. In salt marshes, the prevalent paradigm is that access to marsh resources, such as prey on the marsh plain or exported prey, occurs along the marsh-channel interface such that a greater edge (or area:perimeter ratio) will have a higher attraction and function for mobile coastal fauna. Similarly, increased concentration of zooplankton and meiofauna along seagrass edges might be an explanatory mechanism for greater nekton abundance along seagrass edges (Macreadie et al. 2010). Most edge response studies are short-duration observations, conducted during daylight hours and carried out with no a priori predictions. This is likely to bias results, because many species make nocturnal forays across ecosystem boundaries to feed or use edges only when risk from predation is reduced.

\section{Infaunal responses to seagrass configuration}

Infaunal responses to seagrass patch attributes and habitat configuration are still understudied compared to epifauna and fishes. This is unexpected, because such responses are likely important in explaining spatial distributions of higher trophic levels in patchy environments. Generally, studies have focused on 3 topics: (1) patch size effects (Bowden et al. 2001, Hirst \& Attrill 2008); (2) patch edge effects (Bell et al. 2001, Bowden et al. 2001, Bologna \& Heck 2002, Tanner 2005, Boström et al. 2006b); and (3) effects of broad-scale habitat configuration/fragmentation (Frost et al. 1999, Turner et al. 1999, Rakocinski et al. 2008, Mills \& Berkenbusch 2009). Broad-scale (1 to $50 \mathrm{~km}$ ) fragmentation studies on infauna are still few, and confounding effects of exposure, depth, habitat complexity, and time complicates direct comparisons of configuration effects (Rakocinski et al. 2008, Mills \& Berkenbusch 2009), but see Turner et al. (1999) for separation of the influence of patch, landscape, and temporal variability on infauna. Unlike epifauna and fish, infauna appear to be less influenced by aboveground structure (except during the settling phase for some taxa), and the key mechanism maintaining high density and diversity is sediment stability provided by the belowground rhizome network.

While most infauna taxa appear to be more abundant in large patches or show similar densities in both small and large patch sizes, some taxa (e.g. oligochaetes, nematodes, and the polychaete Capitella sp.) seem to occur at higher densities in small patches. Such patterns may be explained by differences in infaunal life-history and functional traits. Reproductive type, feeding habits, and larval type have been identified as important factors influencing dispersal and community development and composition (Bremner et al. 2006). Other inconsistencies such as low versus high densities of Capitellidae along patch edges in Australia and the UK, respectively (Bowden et al. 2001, Tanner 2005), and between various polychaete families (Tanner 2005) also have been reported. Other taxa that seem to be edge specialists are tanaids and isopods (Bowden et al. 2001, Tanner 2005). The mechanisms causing such interioredge differences are poorly understood, but speciesspecific susceptibility to predation, differing grain size, and organic content preferences or dissimilar feeding modes and reproductive strategies across infaunal taxa are all possible factors that warrant further study. How- 
ever, prevalence for fragmented (edge) habitats might vary between taxon and site (Mills \& Berkenbusch (2009). Thus, although tanaids (Leptochelia savignyi) and amphipods (Phoxocephalidae sp.) were found in higher numbers in continuous meadows at one site, they exhibited much higher abundances in fragmented seagrass at the other study site. Such results are likely influenced by the relative position of the patches in relation to site-specific environmental gradients (Mills \& Berkenbusch 2009).

\section{Non-linearities in animal-habitat configuration relationships}

As coastal biogenic habitats are fragmented or lost (Tables 1 \& 2), a central question is whether animal population size or some other relevant ecological response variable will change linearly in relation to changes in habitat configuration, or whether faunal responses are characterized by non-linear relationships and sudden changes or so called 'critical thresholds' as reported for terrestrial landscapes (Swift \& Hannon 2010). Non-linearities occur in both seagrass patch growth - and thus seascape formation (Sintes et al. 2005) - and in physical processes (wave attenuation) in coastal habitats (Koch et al. 2009), but similar responses by animals inhabiting these systems have not been synthesized.

One of the earliest examples of potential seascape configuration thresholds implied that transfer of secondary production increased abruptly when seagrass cover decreased from 99 to $70 \%$, while no further increase in energy transfer was recorded in very patchy (23\% cover) seagrass landscapes (Irlandi 1994). Fonseca \& Bell (1998) proposed a critical coverage level of 50 to $59 \%$ in seagrass ecosystems, below which loss of integrity decreases with increasing habitat fragmentation. The seascape literature currently includes several other examples of potential thresholds and non-linear species-habitat relationships. Mobile fauna seem to tolerate significant changes in seagrass vegetation cover. For example, Pittman et al. (2004) identified a linear decrease in density and diversity of fishes and decapods as seagrass cover decreased along a gradient until ca. $20 \%$ seagrass cover, where an abrupt decline in fauna was recorded. Similarly, Reed \& Hovel (2006) showed that removal of up to $50 \%$ of seagrass had minor impact on the number, richness, and composition of seagrass epifauna, while a shift in epifaunal species richness and density was only evident in plots with $90 \%$ habitat removal.

Strong positive parabolic relationships between seagrass cover and fish abundance have also been recorded, with highest fish abundances in both continuous (95\% cover) and discontinuous (16\% cover) seagrass landscapes. This result suggests that conditions are suboptimal for fish at 55 to $65 \%$ cover (Salita et al. 2003). Also in a temperate seagrass seascape consisting of patches between 1 and $80 \mathrm{~m}^{2}$, predation risk of juvenile cod was best described with a parabolic function, where predation losses were highest at a threshold patch size of $25 \mathrm{~m}^{2}$ (Gorman et al. 2009). Perhaps the most convincing evidence of strong parabolic relationships between fish and seagrass ecosystem configuration is from Newfoundland, Canada, where Thistle et al. (2010) found strong parabolic relationships between fish density and eelgrass patchiness across several fish species and spatial scales (Table 3). Furthermore, recent work on the multi-scale relationships between 3-dimensional topographic complexity and fish distributions has detected distinct threshold effects for some coral reef species that exhibit a sensitive dependence for architecturally complex reefs (Pittman et al. 2009). Explanations put forward to explain parabolic relationships between fish and habitat configuration include food availability, predation risk, or a combination of both. For instance, juvenile cod (Gadus morhua) forage for zooplankton and invertebrates over the unvegetated matrix, and reduce their own predation risk by using the structure provided by patchy vegetation (Laurel et al. 2003, Thistle et al. 2010). Also, pipefish respond to increased food availability (e.g. copepods) along seagrass patch edges (Smith et al. 2008, Warry et al. 2009). However, strong diurnal patterns may also influence spatial patterns of fish foraging in patchy seagrass seascapes (Jackson et al. 2006b). In seagrasses, predation risk is higher along edges (Irlandi 1994, Bologna \& Heck 1999a, Peterson et al. 2001) as well as in larger patches and connected ecosystems due to higher predator densities (Hovel \& Lipcius 2001, Laurel et al. 2003). Thus, predation may explain avoidance of very patchy as well as continuous vegetation, causing parabolic distributions (Salita et al. 2003).

Despite the association of salt marsh nekton with ecosystem edges (see 'Results - Spatial pattern metrics and faunal response variables - Edge effects Salt marshes'), and parabolic models suggesting a maximum amount of edge in marsh seascapes with 60 to $70 \%$ cover (Browder et al. 1989, Minello \& Rozas 2002), few quantitative values for critical thresholds unique to tidal marsh seascapes have been described to date. On the other hand, simulation models suggest that survival of brown shrimp peaks at intermediate levels of fragmentation patterns in marsh seascapes characterized by large amounts of edge habitat, while less and more severe disintegration results in lower shrimp survival and density estimates (Browder et al. 1989, Haas et al. 2004) (Table 3). There is a scarcity of examples that describe the shape of population response curves to marsh-water configurations. However, sigmoid relationships between nekton produc- 
tion and salt marsh landscape pattern have been demonstrated. For example, Kneib (2003) described steep declines in both resident and migrant nekton production when the amount of marsh edge within a $200 \mathrm{~m}$ radius of a sampling point dropped below a $3000 \mathrm{~m}$ threshold. However, duration of tidal inundation, i.e. intertidal foraging time for nekton, was believed to influence any underlying relationship between marsh edge and nekton production derived from intertidal resources. In a broader watershed view, there appear to be thresholds in relationships between detectable environmental effects on physical, chemical, and biological components of tidal marsh creeks and the amount of impervious surface in adjacent upland areas (e.g. Lerberg et al. 2000, Holland et al. 2004) that are similar to those reported for freshwater riverine watersheds (Booth \& Jackson 1997).

\section{Applications in coastal management and spatial planning}

Although strong evidence of biotic response to some spatial patterns in coastal ecosystems would argue for incorporating the underlying concepts into coastal restoration and protection strategies and designs, the published literature has yet to provide much guidance or case studies. Despite numerous terrestrial studies that argue for restoration of fragmented landscapes to increase biodiversity and abundance of targeted atrisk taxa (Palmer 2009), this has generally not been substantiated for coastal restoration.

The application of a landscape ecology approach in the management of salt marshes has provided a broader view of the importance of maintaining spatial heterogeneity to accommodate not only the requirements of multiple species (Larkin et al. 2008), but also an explicit consideration of humans as integral components of coastal seascapes (Weinstein 2008). Some large-scale preservation and restoration efforts in marsh ecosystems in the USA have specifically relied on applying recognized relationships between the marsh seascape, tidal hydrodynamics, and the export of fish production to the open estuary (Weishar et al. 2005). Relationships between channel geomorphology, tidal activity, and use of marsh ecosystems by faunal components have been applied to evaluate restoration projects in California (Larkin et al. 2008) as well as manipulations of the marsh seascape for mosquito control in New Jersey (Lathrop et al. 2000). In addition, the regional focus on the importance of edge in the production of fisheries species also has driven a number of smaller-scale marsh restoration projects in the Gulf of Mexico (Rozas et al. 2005, 2007, Rozas \& Minello 2007). Furthermore, modeling results suggest that salt marsh nekton population size may ben- efit from simulated addition of channel edge (Minello \& Rozas 2002). Allometric form (outlet width and depth, channel length, perimeter, and surface area) of tidal channels may constitute valuable templates for tidal channel restoration. For example, Hood (2002a) argued that allometric relationships that can be related to ecological performance (e.g. anadromous fish use), benefit restoration design and assessment by (1) loosening sizerelated constraints on replication for landscape-scale studies; (2) maximizing physical and ecological predictability; (3) providing insight into undocumented human disturbances; and (4) suggesting allometry-based design goals and criteria for success.

For conservation efforts to be successful, the abundance, proximity, and composition of different habitat types within patch mosaics needs to be considered. Coral reefs and mangroves exhibit complex spatial patterning at a range of spatial scales (Fig. 1), yet relatively few studies have quantified the seascape composition and spatial configuration. The majority of work has focused instead on the juxtaposition of habitat types and their relative proximity or the absence/loss of key habitat types on faunal distributions. Many of these studies did not adopt a landscape ecology approach whereby spatial attributes of patch structure and patch context are quantified. The influence of patch types adjacent to coral reefs and mangroves has long been known as an important factor determining the structure and ecological function of these interconnected systems (Nagelkerken et al. 2001). Where patch mosaics have been analyzed, seascape composition and organization appears to elicit a stronger faunal response than spatial configuration. This has clear implications for both the way we approach the study of fish-habitat relationships and for conservation efforts. Research on juvenile fish species in mangrove seascapes indicates that higher survival is associated with certain seascape types. For example, certain fish species with life histories that require habitat-specific ontogenetic shifts may successfully transition through all life stages only when mangroves exist in close proximity to seagrasses and coral reefs to provide sufficient stage-specific food resources and predator refugia (Nagelkerken et al. 2001, Pittman \& McAlpine 2003).

Identification of functionally integrated seascape types involves a perceptual shift away from a focus on single patch types to a consideration of interrelated functions provided by mosaics of habitat types (Pittman et al. 2007). This information can be used to help design restoration strategies or to ensure that a suite of resources is protected so that the seascape functions well for the support of species, assemblages, and communities of interest. This will guide investments that are targeted at achieving ecologically meaningful goals and objectives and increase the likelihood of success in con- 
servation. Such information can also assist in identifying essential fish habitat, which would also be enhanced through consideration of seascape types versus the more conventional individual patch types, particularly for multi-habitat species. Although commonly implemented in terrestrial environments and known as 'conservation design,' few coastal examples exist where restoration actions are strategically chosen to enhance faunal populations through ecologically functional seascape configurations. One large-scale example from a salt marsh in Delaware Bay (USA) was described by Teal \& Peterson (2005) and associated contributions. Landscape ecology concepts related to size and shape, connectivity and spacing, and diversity of target habitats have been incorporated into MPA design criteria (Roberts et al. 2003, McLeod et al. 2009). Fewer studies have incorporated seascape structure in comparative studies of MPA effectiveness. This is problematic because most MPAs are sighted around areas of local interest which may include the best examples of coastal ecosystems. Therefore, it is important to account for variability in the underlying seascape composition and configuration in explaining variability in performance and in untangling the relative influence of compliance or enforcement or other factors. Likewise, the seascape structure surrounding an MPA may influence the ecological functioning inside the MPA. Ultimately, the achievement of more sustainable and ecologically functional coastal seascapes will require more adherence to protecting and restoring the natural ecosystem processes that promote natural 'designs' rather than 'designing' restoration and preservation.

\section{Future research priorities for seascape ecology}

\section{Habitat fragmentation}

The results of our synopsis of the state of this science suggests that the next generation of fragmentation research should (1) more clearly address what type of seascape change (e.g. patch fragmentation) is measured, such as the effects of a static arrangement of patches illustrating the (long-term) end result of a naturally patchy system, or the (short-term) effects of active habitat fragmentation mimicking stochastic disturbance events; (2) consider the portion of sensitive (ecologically specialized) versus insensitive (habitat generalist) species in the system in order to evaluate acute versus chronic seascape scenarios; (3) identify risk regions, i.e. highly fragmented areas under risk of likely loss due to future anthropogenic pressures, or due to the negative cascading effects that loss of a habitat might have on adjacent elements in the seascape; and (4) design surveys and experiments to identify and assess the generality of possible nonlinear faunal responses and critical thresholds to changes in habitat configuration across species and systems.

\section{Edge effects}

Ries \& Sisk (2004) provided a predictive framework for faunal responses (changes in abundance) to edges based on an assumption that the relative availability of resources between patches is a key driver of responses. If access to prey assemblages drives nekton edge responses, future edge studies could focus more on explicit tests of that hypothesis in different seascapes, and routinely incorporate prey species sampling in descriptive and experimental edge studies (Smith et al. 2008, Warry et al. 2009). Studies are now needed in different biogenic ecosystems to examine species and even life historystage specific sensitivities to edge that could also be influenced by behavioral and anatomical attributes such as mobility, access to mates, body size, schooling and other predator evasion tactics, and diet.

\section{Animal movements and connectivity}

Relationships among seascape patterns, connectivity, and animal movements are among the most overlooked applications of landscape ecology to coastal environments and likely to be an area of intense activity as the data, tools, and technology needed to address this topic become more widely available. In particular, more studies are now required to gain a broader and deeper understanding of the link between patch connectivity and coastal organism distributions. This will allow us to identify optimal seascape types and determine whether thresholds or tipping points exist in structural connectivity that if exceeded could disrupt functional connectivity such as the transitioning between critical stages of the life cycle.

\section{Oyster reefs}

The processes and faunal interactions in many coastal habitats have not been effectively examined in the seascape context e.g. macroalgae/kelp systems, but among those we examined, oyster reefs are clearly understudied from a landscape point of view. This is surprising given their high global loss rates (Beck et al. 2009), their importance for coastal ecosystem function (Peterson et al. 2003), and their critical role as links in coastal seascapes (Micheli \& Peterson 1999, Shervette \& Gelwick 2008). As oyster reefs form landscape mosaics with patches ranging in size from single shells 
to kilometer-wide reefs (Fig. 1), future manipulative work should focus on the role of patch size, shape, elevation, and isolation to determine how these features affect ecosystem processes and associated faunal diversity. Such experiments may be particularly valuable for understanding optimal reef design in restoration programs (Grizzle et al. 2006).

Thus, while previous studies have provided a good basis for understanding coastal organism-seascape links and patterns, future research efforts should aim at linking spatial patterning of biogenic ecosystems and their component habitats to organism behavior and ecosystem functioning (Lima \& Zollner 1996). This requires novel interdisciplinary approaches, better use of the latest technology and analytical methods (Treml et al. 2008), and perhaps most importantly, an in-depth understanding of the biology of marine organisms, including life cycle analysis, recruitment patterns and bottlenecks, movement behavior, and residence times.

\section{CONCLUDING REMARKS}

Landscape ecology principles have not been applied extensively to coastal ecosystems, with most examples and arguably greatest advances gained from studies of vegetated soft sediment patch types such as seagrass meadows and salt marshes. In addition, studies using a seascape approach on other important ecosystems such as coral reefs and mangrove forests are emerging. Thresholds in animal-habitat associations in coastal biogenic ecosystems appear to be common but also species, habitat, and site specific. Conversely, studies of faunal interactions with variation in the broader seascape composition and organization are still poorly represented. Although dominant (and well documented) mobile species of fish and epifauna seem robust in the face of habitat loss at smaller scales, extrapolations across species and organism groups, habitats, and spatio-temporal scales should be avoided. Significant efforts are now needed to expand seascape ecology to seagrass and salt marsh systems outside the US and Australia, and thus provide critical comparative framework to assess the generality of results obtained during the first $30 \mathrm{yr}$ of seascape ecology. From a theoretical perspective, seascape ecology has great potential to enhance our understanding and management of coastal environments. Substantial efforts are now required to apply and evaluate landscape ecology concepts and analytical techniques to coastal species and ecosystems, and thus further develop this exciting new frontier in coastal science. Technological advances in acoustic and optical remote sensing, geographical information systems, spatial analysis, and acoustic technologies can provide the data and tools to facilitate multi-scale analyses and track move- ments of individuals. Together with the realization that important changes are occurring to biogenic ecosystems at a range of scales, these technological catalysts are set to propel seascape ecology and the associated conceptual frameworks into mainstream coastal ecology.

Acknowledgements. The Research Institute of the Åbo Akademi University Endowment is acknowledged for providing financial support to C.B. to attend the seascape ecology session at the Coastal and Estuarine Research Federation annual conference in November 2009 in Portland, OR, USA. S.J.P. acknowledges the support of the NOAA Biogeography Branch and NOAA Coral Reef Conservation Program; R.T.K. acknowledges the University of Georgia President's Venture Fund for providing travel support, and C.S. acknowledges the support of the National Science Foundation.

\section{LITERATURE CITED}

Able KW, Hagan SM, Brown SA (2003) Mechanisms of marsh habitat alteration due to Phragmites: response of young-ofthe-year mummichog (Fundulus heteroclitus) to treatment for Phragmites removal. Estuaries 26:484-494

- Acosta CA (1999) Benthic dispersal of Caribbean spiny lobsters among insular habitats: implications for the conservation of exploited marine species. Conserv Biol 13:603-612

Acosta CA, Robertson DN (2002) Diversity in coral reef fish communities: the effects of habitat patchiness revisited. Mar Ecol Prog Ser 227:87-96

Airoldi L, Beck MW (2007) Loss, status and trends for coastal marine habitats of Europe. Oceanogr Mar Biol Annu Rev 45:345-405

Allen DM, Haertel-Borer SS, Milan BJ, Bushek D, Dame RF (2007) Geomorphological determinants of nekton use of intertidal salt marsh creeks. Mar Ecol Prog Ser 329:57-71

Allen TFH (1998) The landscape 'level' is dead: persuading the family to take it off the respirator. In: Peterson DL, Parker VT (eds) Ecological scale. Columbia University Press, New York, NY, p 35-54

Ault TR, Johnson CR (1998a) Spatially and temporally predictable fish communities on coral reefs. Ecol Monogr 68: $25-50$

Ault TR, Johnson CR (1998b) Spatial variation in fish species richness on coral reefs: habitat fragmentation and stochastic structuring processes. Oikos 82:354-364

Baltz DM, Rakocinski C, Fleeger JW (1993) Microhabitat use by marsh-edge fishes in a Louisiana estuary. Environ Biol Fishes 36:109-126

> Barberá-Cebrián C, Sánchez-Jerez P, Ramos-Esplá AA (2002) Fragmented seagrass habitats on the Mediterranean coast, and distribution and abundance of mysid assemblages. Mar Biol 141:405-413

Beck MB, Brumbaugh RD, Airoldi L, Carranza A and others (2009) Shellfish reefs at risk: a global analysis of problems and solutions. The Nature Conservancy, Arlington, VA

Bell JD, Westoby M (1986) Variation in seagrass height and density over a wide spatial scale: effects on common fish and decapods. J Exp Mar Biol Ecol 104:275-295

Bell SS, Brooks RA, Robbins BD, Fonseca MS, Hall MO (2001) Faunal response to fragmentation in seagrass habitats: implications for seagrass conservation. Biol Conserv 100: 115-123

Bell SS, Hall M, Soffian S, Madley K (2002) Assessing the impact of boat propeller scars on fish and shrimp utilizing seagrass beds. Ecol Appl 12:206-217 
Bologna PAX, Heck KL Jr (1999a) Differential predation and growth rates of bay scallops within a seagrass habitat. J Exp Mar Biol Ecol 239:299-314

Bologna PAX, Heck KL Jr (1999b) Macrofaunal associations with seagrass epiphytes: relative importance of trophic and structural characteristics. J Exp Mar Biol Ecol 242:21-39

Bologna PAX, Heck KL Jr (2000) Impacts of seagrass habitat architecture on bivalve settlement. Estuaries 23:449-457

Bologna PAX, Heck KL Jr (2002) Impact of habitat edges on density and secondary production of seagrass-associated fauna. Estuaries 25:1033-1044

Booth DB, Jackson CR (1997) Urbanization of aquatic systems: degradation thresholds, stormwater detection, and the limits of mitigation. J Am Water Resour Assoc 33:1077-1090

Boström C, Jackson EL, Simenstad CA (2006a) Seagrass landscapes and their effects on associated fauna: a review. Estuar Coast Shelf Sci 68:383-403

> Boström C, Lastuniemi M, Bonsdorff E (2006b) Infaunal responses to habitat structure: a study of life-history traits and population dynamics of Corophium volutator (Pallas). Mar Biol Res 2:398-410

> Bowden DA, Rowden AA, Attrill MJ (2001) Effects of patch size and in-patch location on the infaunal macroinvertebrate assemblages of Zostera marina seagrass beds. J Exp Mar Biol Ecol 259:133-154

Bremner J, Rogers SI, Frid CLJ (2006) Methods for describing ecological functioning of marine benthic assemblages using biological traits analysis (BTA). Ecol Indic 6:609-622

Brooks RA, Bell SS (2001) Mobile corridors in marine landscapes: enhancement of faunal exchange at seagrass/sand ecotones. J Exp Mar Biol Ecol 264:67-84

Browder JA, May LN Jr, Rosenthal A, Gosselink JG, Baumann RH (1989) Modeling future trends in wetland loss and brown shrimp production in Louisiana using thematic mapper imagery. Remote Sens Environ 28:45-59

Burfeind DB, Stunz GW (2006) The effects of boat propeller scarring intensity on nekton abundance in subtropical seagrass meadows. Mar Biol 148:953-962

Caley JD, Buckley KA, Jones GP (2001) Separating ecological effects of habitat fragmentation, degradation and loss on coral commensals. Ecology 82:3435-3448

Chittaro PM (2002) Species-area relationships for coral reef fish assemblages of St Croix, US Virgin Islands. Mar Ecol Prog Ser 233:253-261

Cicchetti G, Diaz RJ (2000) Types of salt marsh edge and export of trophic energy from marshes to deeper habitats. In: Weinstein MP, Kreeger DA (eds) Concepts and controversies in tidal marsh ecology. Kluwer Academic Publishers, Dordrecht, p 515-541

Connolly RM, Hindell JS (2006) Review of nekton patterns and ecological processes in seagrass landscapes. Estuar Coast Shelf Sci 68:433-444

Costanza R, d'Arge R, de Groot R, Farber S and others (1997) The value of the world's ecosystem services and natural capital. Nature 387:253-260

Covi MP, Kneib RT (1995) Intertidal distribution, population dynamics and production of the amphipod Uhlorchestia spar?tino?phila in a Georgia, USA, salt marsh. Mar Biol 121: $447-455$

> Crowder L, Norse E (2008) Essential ecological insights for marine ecosystem-based management and marine spatial planning. Mar Policy 32:772-778

> Darcy MC, Eggleston DB (2005) Do habitat corridors influence animal dispersal and colonization in estuarine systems? Landsc Ecol 20:841-855

> Dean AF, Bollens SM, Simenstad C, Cordell J (2005) Marshes as sources or sinks of an estuarine mysid: demographic patterns and tidal flux of Neomysis kadiakensis at China Camp marsh, San Francisco estuary. Estuar Coast Shelf Sci 63:1-11

Dennison WC (2009) Global trajectories of seagrasses, the biological sentinels of coastal ecosystems. In: Duarte CM (ed) Global loss of coastal habitats: rates, causes and consequences. Fundación BBVA, Bilbao, Spain, p 91-108

> Desmond JS, Zedler JB, Williams GD (2000) Fish use of tidal creek habitats in two southern California salt marshes. Ecol Eng 14:233-252

Didham RK (1997) An overview of invertebrate responses to forest fragmentation. In: Watt AD, Stork NE, Hunter M (eds) Forests and insects. Chapman \& Hall, London, p 303-320

Doak DF, Marino PC, Kareiva PM (1992) Spatial scale mediates the influence of habitat fragmentation on dispersal success: implications for conservation. Theor Popul Biol 41:315-336

> Dorenbosch M, Grol MGG, Nagelkerken I, van der Velde G (2005) Distribution of coral reef-seagrass gradient: edge effects and habitat segregation. Mar Ecol Prog Ser 299: $277-288$

> Drew CA, Eggleston DB (2008) Juvenile fish densities in Florida Keys mangroves correlate with landscape characteristics. Mar Ecol Prog Ser 362:233-243

Duarte CM (2009) Global loss of coastal habitats: rates, causes and consequences. Fundación BBVA, Bilbao, Spain

> Duarte CM, Dennison WC, Orth RJW, Carruthers TJB (2008) The charisma of coastal ecosystems: addressing the imbalance. Estuar Coast 31:233-238

Dunning JB, Danielson BJ, Pulliam HR (1992) Ecological processes that affect populations in complex landscapes. Oikos 65:169-175

Eggleston DB (1999) Applications of landscape ecological principles to oyster reef habitat restoration. In: Luckenbach MW, Mann R, Wesson J (eds) Oyster reef habitat restoration: a synopsis and synthesis of approaches. Virginia Institute of Marine Science Press, Gloucester Point, VA, p 213-227

Eggleston DB, Etherington LL, Elis WE (1998) Organism response to habitat patchiness: species and habitatdependent recruitment of decapod crustaceans. J Exp Mar Biol Ecol 223:111-132

Eggleston DB, Ward EE, Etherington LL, Dahlgren CP, Posey $\mathrm{MH}$ (1999) Organism responses to habitat fragmentation and diversity: habitat colonization by estuarine macrofauna. J Exp Mar Biol Ecol 236:107-132

Ewel KC, Cressa C, Kneib RT, Lake PS and others (2001) Managing critical transition zones. Ecosystems 4:452-460

Fahrig L (2003) Effects of habitat fragmentation on biodiversity. Annu Rev Ecol Evol Syst 34:487-515

- Faunce CH, Serafy JE (2006) Mangroves as fish habitat: 50 years of field studies. Mar Ecol Prog Ser 318:1-18

Fernandez TV, Milazzo M, Badalamentti F, D'Anna G (2005) Comparison of the fish assemblages associated with Posidonia oceanica after the partial loss and consequent fragmentation of the meadow. Estuar Coast Shelf Sci 65:645-653

Fleeger JW, Johnson DS, Galván KA, Deegan LA (2008) Topdown and bottom-up control of infauna varies across the salt marsh landscape. J Exp Mar Biol Ecol 357:20-34

Fonseca MS, Bell SS (1998) Influence of physical setting on seagrass landscapes near Beaufort, North Carolina, USA. Mar Ecol Prog Ser 171:109-121

Fonseca MS, Kenworthy WJ, Colby DR, Rittmaster KA, Thayer GW (1990) Comparisons of fauna among natural and transplanted eelgrass Zostera marina meadows: criteria for mitigation. Mar Ecol Prog Ser 65:251-264

Frost MT, Rowden AA, Attrill MJ (1999) Effect of habitat fragmentation on the macroinvertebrate infaunal communities associated with the seagrass Zostera marina L. Aquat Conserv 9:255-263

Gillanders BM, Able KW, Brown JA, Eggleston DB, Sheridan 
PF (2003) Evidence for connectivity between juvenile and adult habitats for mobile marine fauna: an important component of nurseries. Mar Ecol Prog Ser 247:281-295

Gladfelter WB, Ogden JC, Gladfelter EH (1980) Similarity and diversity among coral reef fish communities: a comparison between tropical western (Virgin Islands) and tropical central pacific (Marshall Islands) patch reefs. Ecology 61: 1156-1168

Gorman AM, Gregory RS, Schneider DC (2009) Eelgrass patch size and proximity to the patch edge affect predation risk of recently settled age 0 cod (Gadus). J Exp Mar Biol Ecol 371: $1-9$

Grizzle R, Burdick D, Greene J, Abeels H, Capone M (2006) Reef structure alternatives for restoration of oyster (Crassostrea virginica) populations in New Hampshire. Final Report to The New Hampshire Estuaries Project. University of New Hampshire, Durham, NH, p 2-17

Grober-Dunsmore R, Frazer TK, Lindberg WJ, Beets J (2007) Reef fish and habitat relationships in a Caribbean seascape: the importance of reef context. Coral Reefs 26:201-216

Grober-Dunsmore R, Frazer TK, Beets JP, Lindberg WJ, Zwick P, Funicelli NA (2008) Influence of landscape structure on reef fish assemblages. Landsc Ecol 23:37-53

Grober-Dunsmore R, Pittman SJ, Caldow C, Kendall MS, Fraser TK (2009) A landscape ecology approach for the study of ecological connectivity across tropical marine seascapes. In: Nagelkerken I (ed) Ecological connectivity among coral reef ecosystems. Springer, New York, NY p 493-529

Guest MA, Connolly RM (2006) Movement of carbon among estuarine habitats: the influence of salt marsh patch size. Mar Ecol Prog Ser 310:15-24

> Haas HL, Rose KA, Fry B, Minello TJ, Rozas LP (2004) Brown shrimp on the edge: linking habitat to survival using an individual-based simulation model. Ecol Appl 14:1232-1247

Haila Y (2002) A conceptual genealogy of fragmentation research: from island biogeography to landscape ecology. Ecol Appl 12:321-334

> Halpern BS (2004) Are mangroves a limiting resource for two coral reef fishes? Mar Ecol Prog Ser 272:93-98

> Hanski I (2005) Landscape fragmentation, biodiversity loss and the societal response. EMBO Rep 6:388-392

> Hattori A, Kobayashi M (2007) Configuration of small patch reefs and population abundance of a resident reef fish in a complex coral reef landscape. Ecol Res 22:575-581

- Healey D, Hovel KA (2004) Seagrass bed patchiness: effects on epifaunal communities in San Diego Bay, USA. J Exp Mar Biol Ecol 313:155-174

Heck KL Jr, Carruthers TJB, Duarte CM, Hughes AR, Kendrick G, Orth RJ, Williams SW (2008) Trophic transfers from seagrass meadows subsidize diverse marine and terrestrial consumers. Ecosystems 11:1198-1210

Hinchey EK, Nicholson MC, Zajac RN, Irlandi EA (2008) Preface: marine and coastal applications in landscape ecology. Landsc Ecol 23:1-5

Hirst JA, Attrill MJ (2008) Small is beautiful: an inverted view of habitat fragmentation in seagrass beds. Estuar Coast Shelf Sci 78:811-818

Hitt S, Pittman SJ, Nemeth RS (2011) Diel movements of fish are linked to benthic seascape structure in a Caribbean coral reef ecosystem. Mar Ecol Prog Ser 427:275-291

Holland AF, Sanger DM, Gawle CP, Lerberg SB and others (2004) Linkages between tidal creek ecosystems and the landscape and demographic attributes of their watersheds. J Exp Mar Biol Ecol 298:151-178

Hood WG (2002a) Application of landscape allometry to restoration of tidal channels. Restor Ecol 10:213-222

Hood WG (2002b) Landscape allometry: from tidal channel hydraulic geometry to benthic ecology. Can J Fish Aquat Sci 59:1418-1427

Horinouchi M (2009) Horizontal gradient in fish assemblage structures in and around a seagrass habitat: some implications for seagrass habitat conservation. Ichthyol Res 56: 109-125

> Horinouchi M, Tongnunui P, Nanjyo K, Nakamura Y, Sano M, Ogawa H (2009) Differences in fish assemblage structures between fragmented and continuous seagrass beds in Trang, southern Thailand. Fish Sci 75:1409-1416

> Hovel KA (2003) Habitat fragmentation in marine landscapes: relative effects of habitat cover and configuration on juvenile crab survival in California and North Carolina seagrass beds. Biol Conserv 110:401-412

- Hovel KA, Fonseca MS (2005) Influence of seagrass landscape structure on the juvenile blue crab habitat-survival function. Mar Ecol Prog Ser 300:179-191

Hovel KA, Lipcius RN (2001) Habitat fragmentation in a seagrass landscape: patch size and complexity control blue crab survival. Ecology 82:1814-1829

Hovel KA, Lipcius RN (2002) Effects of seagrass habitat fragmentation on juvenile blue crab survival and abundance. J Exp Mar Biol Ecol 271:75-98

> Hovel KA, Regan HM (2008) Using an individual-based model to examine the roles of habitat fragmentation and behavior on predator-prey relationships in seagrass landscapes. Landsc Ecol 23:75-89

> Hovel KA, Fonseca MS, Myer DL, Kenworthy WJ, Whitfield PE (2002) Effects of seagrass landscape structure, structural complexity and hydrodynamic regime on macrofaunal densities in North Carolina seagrass beds. Mar Ecol Prog Ser 243:11-24

Hughes AR, Williams SL, Duarte CM, Heck KL Jr, Waycott M (2009) Associations of concern: declining seagrasses and threatened dependent species. Front Ecol Environ 7:242-246

Irlandi EA (1994) Large- and small-scale effects of habitat structure on rates of predation: how seagrass landscapes influence rates of predation and siphon nipping on an infaunal bivalve. Oecologia 98:176-183

Irlandi EA (1996) The effects of seagrass patch size and energy regime on growth of a suspension-feeding bivalve. J Mar Res 54:161-185

Irlandi EA (1997) Seagrass patch size and survivorship of an infaunal bivalve. Oikos 78:511-518

> Irlandi EA, Crawford MK (1997) Habitat linkages: the effect of intertidal salt marshes and adjacent subtidal habitats on abundance, movement, and growth of an estuarine fish. Oecologia 110:222-230

Irlandi EA, Ambrose WG, Orlando BA (1995) Landscape ecology and the marine environment: how spatial configuration of seagrass habitat influences growth and survival of the bay scallop. Oikos 72:307-313

Irlandi EA, Orlando BA, Ambrose WG (1999) Influence of seagrass habitat patch size on growth and survival of juvenile bay scallops, Argopecten irradians concentricus (Say). J Exp Mar Biol Ecol 235:21-43

Jackson EL, Attrill MJ, Jones MB (2006a) Habitat characteristics and spatial arrangement affecting the diversity of fish and decapod assemblages of seagrass (Zostera marina) beds around the coast of Jersey (English Channel). Estuar Coast Shelf Sci 68:421-432

Jackson EL, Attrill MJ, Rowden AA, Jones MB (2006b) Seagrass complexity hierarchies: influence of fish groups around the coast of Jersey (English Channel). J Exp Mar Biol Ecol 330:38-54

Jelbart JE, Ross PM, Connolly RM (2006) Edge effects and patch size in seagrass landscapes: an experimental test using fish. Mar Ecol Prog Ser 319:93-102 
Jelbart JE, Ross PM, Connolly RM (2007) Patterns of small fish distributions in seagrass beds in a temperate Australian estuary. J Mar Biol Assoc UK 87:1297-1307

Jin B, Qin H, Xu W, Wu J and others (2010) Nekton use of intertidal creek edges in low salinity salt marshes of the Yangtze River estuary along a stream-order gradient. Estuar Coast Shelf Sci 88:419-428

Johannes RE (1978) Reproductive strategies of coastal marine fishes in the tropics. Environ Biol Fishes 3:65-84

Johnson LB, Gage SH (1997) Landscape approaches to the analysis of aquatic ecosystems. Freshw Biol 37:113-132

Johnson MW, Heck KL Jr (2006) Effects of habitat fragmentation per se on decapods and fishes inhabiting seagrass meadows in the northern Gulf of Mexico. Mar Ecol Prog Ser 306:233-246

Kelly JP, Stralberg D, Etienne K, McCaustland M (2008) Landscape influence on the quality of heron and egret colony sites. Wetlands 28:257-275

Kendall MS, Christensen JD, Hillis-Starr Z (2003) Multi-scale data used to analyze the spatial distribution of French grunts, Haemulon flavolineatum, relative to hard and soft bottom in a benthic landscape. Environ Biol Fishes 66:19-26

Kendall MS, Miller TJ, Pittman SJ (2011) Patterns of scaledependency and the influence of map resolution on the seascape ecology of reef fish. Mar Ecol Prog Ser 427:259-274

King AW (2005) Hierarchy theory and the landscape level? or, Words do matter. In: Wiens J, Moss M (eds) Issues and perspectives in landscape ecology. Cambridge Studies in Landscape Ecology Series. Cambridge University Press, Cambridge, p 29-36

Kneib RT (1984) Patterns of invertebrate distribution and abundance in the intertidal salt marsh: causes and questions. Estuaries 7:392-412

Kneib RT (1992) Population dynamics of the tanaid Hargeria rapax (Crustacea: Pericarida) in a tidal marsh. Mar Biol 113:437-445

Kneib RT (1994) Spatial pattern, spatial scale, and feeding in fishes. In: Stouder DJ, Fresh KL, Feller RJ (eds) Theory and application in fish feeding ecology. University of South Carolina Press, Columbia, SC, p 169-185

Kneib RT (1997) The role of tidal marshes in the ecology of estuarine nekton. Oceanogr Mar Biol Annu Rev 35: $163-220$

Kneib RT (2000) Salt marsh ecoscapes and production transfers by estuarine nekton in the southeastern U.S. In: Weinstein MP, Kreeger DA (eds) Concepts and controversies in tidal marsh ecology. Kluwer Academic Publishers, Dordrecht, p 267-291

Kneib RT (2003) Bioenergetic and landscape considerations for scaling expectations of nekton production from intertidal marshes. Mar Ecol Prog Ser 264:279-296

Kneib RT (2009) Genotypic variation does not explain differences in growth of mummichogs Fundulus heteroclitus from simple and complex tidal marsh landscapes. Mar Ecol Prog Ser 386:207-219

Koch EW, Barbier EB, Silliman BR, Reed DJ and others (2009) Non-linearity in ecosystem services: temporal and spatial variability in coastal protection. Front Ecol Environ 7:29-37

Kunza AE, Pennings SC (2008) Patterns of plant diversity in Georgia and Texas salt marshes. Estuar Coast 31:673-681

> Larkin DJ, Madon SP, West JM, Zedler JB (2008) Topographic heterogeneity influences fish use of an experimentally restored tidal marsh. Ecol Appl 18:483-496

- Lathrop RG, Cole MB, Showalter RD (2000) Quantifying the habitat structure and spatial pattern of New Jersey (U.S.A.) salt marshes under different management regimes. Wetl Ecol Manag 8:163-172

Laurel BJ, Gregory RS, Brown JA (2003) Predator distribution and habitat patch area determine predation rates on age-0 juvenile cod Gadus spp. Mar Ecol Prog Ser 251:245-254

Leathwick JR, Moilanen A, Francis M, Elith J, Taylor P, Julian $K$, Hastie $T$ (2008) Novel methods for the design and evaluation of marine protected areas in offshore waters. Conserv Lett 1:91-102

> Lerberg SB, Holland AF, Sanger DM (2000) Responses of tidal creek macrobenthic communities to the effects of watershed development. Estuaries 23:838-853

> Leslie HM (2005) A synthesis of marine conservation planning approaches. Conserv Biol 19:1701-1713

Levin LA, Boesch DF, Covich A, Dahm C and others (2001) The function of marine critical transition zones and the importance of sediment biodiversity. Ecosystems 4:430-451

$>$ Lewis DB, Eby LA (2002) Spatially heterogeneous refugia and predation risk in intertidal salt marshes. Oikos 96:119-129

> Lima SL, Zollner PA (1996) Towards a behavioral ecology of ecological landscapes. Trends Ecol Evol 11:131-135

Liu J, Taylor WW (2002) Integrating landscape ecology into natural resource management. Cambridge University Press, Cambridge

> Loneragan NR, Adnan NA, Connolly RM, Manson FJ (2005) Prawn landings and their relationship with the extent of mangroves and shallow waters in western peninsular Malaysia. Estuar Coast Shelf Sci 63:187-200

Long W, Burke RP (2007) Habitat size, flora and fauna: interactions in a tidal saltwater marsh. J Exp Mar Biol Ecol 353: $80-88$

Lotze HK, Lenihan HS, Bourque BJ, Bradbury RH and others (2006) Depletion, degradation, and recovery potential of estuaries and coastal seas. Science 312:1806-1809

MacArthur RH, Wilson EO (1967) The theory of island biogeography. Princeton University Press, Princeton, NJ

Macreadie PI, Hindell JS, Jenkins GP, Connolly RM, Keough MJ (2009) Fish responses to experimental fragmentation of seagrass habitat. Conserv Biol 23:644-652

Macreadie PI, Connolly RM, Jenkins GP, Hindell JS, Keough MJ (2010) Edge patterns in aquatic invertebrates explained by predictive models. Mar Freshw Res 61:214-218

- Manson FJ, Loneragan NR, Harch BD, Skilleter GA, Williams L (2005) A broad-scale analysis of links between coastal fisheries production and mangrove extent: a case-study for northeastern Australia. Fish Res 74:69-85

Marlow JA, Harrison T, Rastogi A, Vu HL, Post JR (2007) Fish communities in continuous and patch mangrove habitats on Little Cayman Island. Dartmouth Stud Trop Ecol 17: 221-225

> McArthur LC, Boland JW (2006) The economic contribution of seagrass to secondary production in South Australia. Ecol Model 196:163-172

> McGarigal K, Cushman SA (2002) Comparative evaluation of experimental approaches to the study of habitat fragmentation. Ecol Appl 12:335-345

McGarigal K, Marks BJ (1994) FRAGSTATS, spatial pattern analysis program for quantifying landscape structure, v20. Forest Science Department, Oregon State University, Corvallis, OR

> McLeod E, Salm R, Green A, Almany J (2009) Designing marine protected area networks to address the impacts of climate change. Front Ecol Environ 7:362-370

> McNeill SE, Fairweather PG (1993) Single large or several small marine reserves? An experimental approach with seagrass fauna. J Biogeogr 20:429-440

Meentemeyer V (1989) Geographical perspectives of space, time, and scale. Landscape Ecol 3:163-173

Meyer DL, Posey MH (2009) Effects of life history strategy on fish distribution and use of estuarine salt marsh and shallow-water flat habitats. Estuar Coasts 32:797-812 
Meynecke JO, Lee SY, Duke NC (2008) Linking spatial metrics and fish catch reveals the importance of coastal wetland connectivity to inshore fisheries in Queensland, Australia. Biol Conserv 141:981-996

Micheli F, Peterson CH (1999) Estuarine vegetated habitats as corridors for predator movements. Conserv Biol 13:869-881

Mills VS, Berkenbusch K (2009) Seagrass (Zostera muelleri) patch size and spatial location influence infaunal macroinvertebrate assemblages. Estuar Coast Shelf Sci 81:123-129

Minello TJ, Rozas LP (2002) Nekton in Gulf Coast wetlands: fine-scale distributions, landscape patterns, and restoration implications. Ecol Appl 12:441-455

Minello TJ, Zimmerman RJ, Medina R (1994) The importance of edge for natant macrofauna in a created salt marsh. Wetlands 14:184-198

Minello TJ, Matthews GA, Caldwell PA (2008) Population and production estimates for decapod crustaceans in wetlands of Galveston Bay, Texas. Trans Am Fish Soc 137:129-146

Mizerek T, Regan HM, Hovel KA (2011) Seagrass habitat loss and fragmentation influence management strategies for a blue crab Callinectes sapidus fishery. Mar Ecol Prog Ser 427:247-257

Molles MC Jr (1978) Fish species diversity on model and natural reef patches: experimental insular biogeography. Ecol Monogr 48:289-305

> Mumby PJ, Edwards AJ, Arias-Gonzalez JE, Lindeman KC and others (2004) Mangroves enhance the biomass of coral reef fish communities in the Caribbean. Nature 427:533-536

Nagelkerken I, Kleijnen S, Klop T, van den Brand RACJ, Cocheret de la Morinière E, van der Velde G (2001) Dependence of Caribbean reef fishes on mangroves and seagrass beds as nursery habitats: a comparison of fish faunas between bays with and without mangroves/seagrass beds. Mar Ecol Prog Ser 214:225-235

> Nicholls RJ, Hoozemans FMJ, Marchand M (1999) Increasing flood risk and wetland losses due to global sea-level rise: regional and global analyses. Glob Environ Change 9: S69-S87

Odum EP (1958) Fundamentals of ecology, 2nd edn. Saunders, Philadelphia, PA

Overholtzer-McLeod KL (2006) Consequences of patch reef spacing for density-dependent mortality of coral-reef fishes. Ecology 87:1017-1026

Palmer JF (2004) Using landscape metrics to predict scenic perception in a changing landscape: Dennis, Massachusetts. Landsc Urban Plann 69:201-218

Palmer MA (2009) Reforming watershed restoration: science in need of application and application in need of science. Estuar Coasts 32:1-17

Palumbi SR, Sandifer PA, Allan JD, Beck MW and others (2009) Managing for ocean biodiversity to sustain marine ecosystem services. Front Ecol Environ 7:204-211

Paw JN, Chua TE (1991) An assessment of the ecological and economic impact of mangrove conversion in Southeast Asia. Towards an integrated management of tropical coastal resources. ICLARM Conf Proc 22:201-212

> Peterson BJ, Thompson KR, Cowan JH Jr, Heck KL Jr (2001) Comparison of predation pressure in temperate and subtropical seagrass habitats based on chronographic tethering. Mar Ecol Prog Ser 224:77-85

> Peterson CH, Grabowski JH, Powers SP (2003) Estimated enhancement of fish production resulting from restoring oyster reef habitat: quantitative evaluation. Mar Ecol Prog Ser 264:249-264

> Peterson GW, Turner RE (1994) The value of salt marsh edge vs. interior as a habitat for fish and decapod crustaceans in a Louisiana tidal marsh. Estuaries 17:235-262

Pittman SJ, McAlpine CA (2003) Movements of marine fish and decapod crustaceans: process, theory and application. Adv Mar Biol 44:205-294

Pittman SJ, McAlpine CA, Pittman KM (2004) Linking fish and prawns to their environment: a hierarchical landscape approach. Mar Ecol Prog Ser 283:233-254

Pittman SJ, Caldow C, Hile SD, Monaco ME (2007) Using seascape types to explain the spatial patterns of fish in the mangroves of SW Puerto Rico. Mar Ecol Prog Ser 348: $273-284$

Pittman SJ, Costa B, Battista T (2009) Using Lidar bathymetry and boosted regression trees to predict the diversity and abundance of fish and corals. J Coast Res Spec Issue 53: $27-38$

Polidoro BA, Livingstone SR, Carpenter KE, Hutchinson B and others (2008) Status of the world's marine species. In: Vié JC, Hilton-Taylor C, Stuart SN (eds) The 2008 review of the IUCN red list of threatened species. IUCN, Gland, p 1-9

Rakocinski CF, Moncreiff CA, Peterson MA, VanderKoov KE, Randall TA (2008) Habitat condition and associated macrofauna reflect differences between protected and exposed seagrass landscapes. Gulf Caribb Res 20:11-19

> Ray GC (2005) Connectivities of estuarine fishes to the coastal realm. Estuar Coast Shelf Sci 64:18-32

> Reed BJ, Hovel KA (2006) Seagrass habitat disturbance: how loss and fragmentation of eelgrass Zostera marina influences epifaunal abundance and diversity. Mar Ecol Prog Ser 326:133-143

> Reusch TBH (1998) Differing effects of eelgrass Zostera marina on recruitment and growth of associated blue mussels Mytilus edulis. Mar Ecol Prog Ser 167:149-153

> Reusch TBH, Williams SL (1999) Macrophyte canopy structure and the success of an invasive marine bivalve. Oikos 84:398-416

> Ries L, Sisk TD (2004) A predictive model of edge effects. Ecology 85:2917-2926

Robbins BD, Bell SS (1994) Seagrass landscapes: a terrestrial approach to the marine subtidal environment. Trends Ecol Evol 9:301-304

Roberts CM, Branch G, Bustamante RH, Castilla JC and others (2003) Application of ecological criteria in selecting marine reserves and developing reserve networks. Ecol Appl 13: $215-228$

> Roth BM, Rose KA, Rozas LP, Minello TJ (2008) Relative influence of habitat fragmentation and inundation on brown shrimp Farfantepenaeus aztecus production in northern Gulf of Mexico salt marshes. Mar Ecol Prog Ser 359:185-202

> Rozas LP (1995) Hydroperiod and its influence on nekton use of the salt marsh: a pulsing paradigm. Estuaries 18:579-590

> Rozas LP, Minello TJ (2007) Restoring coastal habitat using marsh terracing: the effect of cell size on nekton use. Wetlands 27:595-609

> Rozas LP, Minello TJ (2010) Nekton density patterns in tidal ponds and adjacent wetlands related to pond size and salinity. Estuar Coast 33:652-667

Rozas LP, Reed DJ (1993) Nekton use of marsh-surface habitats in Louisiana (USA) deltaic salt marshes undergoing submergence. Mar Ecol Prog Ser 96:147-157

> Rozas LP, Zimmerman RJ (2000) Small-scale patterns of nekton use among marsh and adjacent shallow nonvegetated areas of the Galveston Bay Estuary, Texas (USA). Mar Ecol Prog Ser 193:217-239

Rozas LP, McIvor CC, Odum WE (1988) Intertidal rivulets and creekbanks: corridors between tidal creeks and marshes. Mar Ecol Prog Ser 47:303-307

Rozas LP, Caldwell P, Minello TJ (2005) The fishery value of salt marsh restoration projects. J Coast Res 40:37-50

> Rozas LP, Minello TJ, Zimmerman RJ, Caldwell P (2007) Nekton populations, long-term wetland loss, and the effect of 
recent habitat restoration in Galveston Bay, Texas, USA. Mar Ecol Prog Ser 344:119-130

Sale PF, Douglas WA (1984) Temporal variability in the community structure of fish on coral patch reefs and the relation of community structure to reef structure. Ecology 65: 409-422

Salita JT, Ekau W, Saint-Paul U (2003) Field evidence on the influence of seagrass landscapes on fish abundances in Bolinao, northern Philippines. Mar Ecol Prog Ser 247: 183-195

Sánchez-Jerez P, Barberá Cebrián C, Ramos Esplá AA (1999) Comparison of the epifauna spatial distribution in Posidonia oceanica, Cymodocea nodosa and unvegetated bottoms: importance of meadow edges. Acta Oecol 20: 391-405

Santos RO, Lirman D, Serafy JE (2011) Quantifying freshwater induced fragmentation of submerged aquatic vegetation communities using a multi-scale landscape ecology approach. Mar Ecol Prog Ser 427:233-246

Shervette VR, Gelwick F (2008) Seasonal and spatial variations in fish and macroinvertebrate communities of oyster and adjacent habitats in a Mississippi estuary. Estuar Coast 31:584-596

> Shriver WG, Hodgman TP, Gibbs JP, Vickery PD (2004) Landscape context influences salt marsh bird diversity and area requirements in New England. Biol Conserv 119:545-553

Sintes T, Marba N, Duarte CM, Kendrick G (2005) Nonlinear processes in seagrass colonisation explained by simple clonal growth rules. Oikos 108:165-175

Sisk TD, Battin J (2002) Habitat edges and avian ecology: geographic patterns and insights for western landscapes. Stud Avian Biol 25:30-48

Smith TM, Hindell JS, Jenkins GP, Connolly RM (2008) Edge effects on fish associated with seagrass and sand patches. Mar Ecol Prog Ser 359:203-213

Smith TM, Hindell JS, Jenkins GP, Connolly RM (2010) Seagrass patch size affects fish responses to edges. J Anim Ecol 79:275-281

Snelgrove PVR, Austen MC, Hawkins SJ, Iliffe TM and others (2004) Vulnerability of marine sedimentary ecosystem services to human activities. In: Wall DH (ed) Sustaining biodiversity and ecosystem services in soils and sediments. Island Press, Washington, DC, p 161-183

Solomon S, Qin D, Manning M, Chen Z and others (eds) (2007) Climate change 2007: the physical science basis: contribution of Working Group I to the fourth assessment report of the Intergovernmental Panel on Climate Change. Cambridge University Press, Cambridge

Spautz H, Nur N, Stralberg D, Chan Y (2006) Multiple-scale habitat relationships of tidal-marsh breeding birds in the San Francisco Estuary. Stud Avian Biol 32:247-269

Swift TL, Hannon SJ (2010) Critical thresholds associated with habitat loss: a review of the concepts, evidence, and applications. Biol Rev Camb Philos Soc 85:35-53

Tanner JE (2003) Patch shape and orientation influences on seagrass epifauna are mediated by dispersal abilities. Oikos 100:517-524

Tanner JE (2005) Edge effects on fauna in fragmented seagrass meadows. Austral Ecol 30:210-218

Tanner JE (2006) Landscape ecology of interactions between seagrass and mobile epifauna: the matrix matters. Estuar Coast Shelf Sci 68:404-412

Teal JM, Peterson SB (2005) Introduction to the Delaware Bay salt marsh restoration. Ecol Eng 25:199-203

Thistle ME, Schneider DC, Gregory RS, Wells NJ (2010) Fractal measures of habitat structure: maximum densities of juvenile cod occur at intermediate eelgrass complexity. Mar Ecol Prog Ser 405:39-56
Thomas BE, Connolly RM (2001) Fish use of subtropical saltmarshes in Queensland, Australia: relationships with vegetation, water depth and distance onto the marsh. Mar Ecol Prog Ser 209:275-288

Tomlinson PB (1986) The botany of mangroves. Cambridge University Press, Cambridge

Treml EA, Halpin PN, Urban DL, Pratson LF (2008) Modeling population connectivity by ocean currents, a graph-theoretic approach for marine conservation. Landsc Ecol 23 (Suppl 1): 19-36

Turner MG (2005) Landscape ecology: What is the state of the science? Annu Rev Ecol Evol Syst 36:319-344

> Turner SJ, Hewitt JE, Wilkinson MR, Morrisey DJ, Thrush SF, Cummings VJ, Funnell G (1999) Seagrass patches and landscapes: the influence of wind-wave dynamics and hierarchical arrangements of spatial structure on macrofaunal seagrass communities. Estuaries 22:1016-1032

Uhrin AV, Holmquist JG (2003) Effects of propeller scarring on macrofaunal use of the seagrass Thalassia testudinum. Mar Ecol Prog Ser 250:61-70

Valiela I, Cole ML, McClelland J, Hauxwell J, Cebrian J, Joye SB (2000) Role of salt marshes as part of coastal landscapes In: Weinstein MP, Kreeger DA (eds) Concepts and controversies in tidal marsh ecology. Kluwer Academic, Dordrecht, p 23-38

Valiela I, Bowen JL, York JK (2001) Mangrove forests: one of the world's most threatened major tropical environments. Bioscience 51:807-815

Valiela I, Kinney E, Culbertson J, Peacock E, Smith S (2009) Global losses of mangroves and salt marshes. In: Duarte CM (ed) Global loss of coastal habitats: rates, causes and consequences. Fundación BBVA, Bilbao, Spain, p 107-138

Vanderklift MA, How J, Wernberg T, MacArthur LD, Heck KL Jr, Valentine JF (2007) Proximity to reef influences density of small predatory fishes, while type of seagrass influences intensity of their predation on crabs. Mar Ecol Prog Ser 340:235-243

Visintainer TA, Bollens SM, Simenstad C (2006) Community composition and diet of fishes as a function of tidal channel geomorphology. Mar Ecol Prog Ser 321:227-243

> Vonk JA, Christianen MJA, Stapel J (2010) Abundance, edge effect, and seasonality of fauna in mixed-species seagrass meadows in southwest Sulawesi, Indonesia. Mar Biol Res 6:282-291

Warry FY, Hindell JS, Macreadie PI, Jenkins GP, Connolly RM (2009) Integrating edge effects into studies of fragmentation: a test using meiofauna in seagrass. Oecologia 159:883-892

Waycott M, Duarte CM, Carruthers TJB and others (2009) Accelerating loss of seagrasses across the globe threatens coastal ecosystems. Proc Natl Acad Sci USA 106:12377-12381

- Webb SR, Kneib R (2002) Abundance and distribution of juvenile white shrimp Litopenaeus setiferus within a tidal marsh landscape. Mar Ecol Prog Ser 232:213-223

- Weinstein MP (2008) Ecological restoration and estuarine management: placing people in the coastal landscape. J Appl Ecol 45:296-304

Weinstein MP, Litvin SY, Guida VG (2005) Considerations of habitat linkages, estuarine landscapes, and the trophic spectrum in wetland restoration design. J Coast Res 40:51-63

- Weishar LL, Teal JM, Hinkle R (2005) Stream order analysis in marsh restoration on Delaware Bay. Ecol Eng 25:252-259

Weslawski JM, Snelgrove PVR, Levin LA, Austen MC and others (2004) Marine sediment biota as providers of ecosystem goods and services. In: Wall DH (ed) Sustaining biodiversity and ecosystem services in soils and sediments. Island Press, Washington, DC, p 73-98

- West JM, Zedler JB (2000) Marsh-creek connectivity: fish use of a tidal salt marsh in southern California. Estuaries 23:699-710 
Whaley SD, Minello TJ (2002) The distribution of benthic infauna of a Texas salt marsh in relation to the marsh edge. Wetlands 22:753-766

Wiens JA (1995a) Habitat fragmentation: island vs. landscape perspectives on bird conservation. Ibis 137 (Suppl S1):S97-S104

Wiens JA (1995b) Landscape mosaics and ecological theory. In: Hansson LL, Fahrig L, Merriam G (eds) Mosaic landscapes and ecological processes. Chapman and Hall, London, p 1-26

Wiens JA (1999) The science and practice of landscape ecology. In: Klopatek JM, Gardner RH (eds) Landscape ecological analysis: issues and applications. Springer-Verlag, New
York, NY, p 372-383

Wiens JA (2002) Riverine landscapes: taking landscape ecology into the water. Freshw Biol 47:501-515

Wiens JA, Milne BT (1989) Scaling of 'landscapes' in landscape ecology, or landscape ecology from a beetle's perspective. Landsc Ecol 3:87-96

Wiens JA, Stenseth NC, Van Horne B, Ims RA (1993) Ecological mechanisms and landscape ecology. Oikos 66:369-380 Wilkinson CR (2008) Status of the coral reefs of the world: 2008. Global Coral Reef Monitoring Network and Australian Institute of Marine Science, Townsville

Appendix 1. Chronological summary of the 118 studies included in this review. FE: field experiment, FS: descriptive field survey, ASU: artificial seagrass unit. Time (d: days, wk: weeks, mo: months, yr/yrs = year/years) refers to the duration of the study; nd: no data

\begin{tabular}{|c|c|c|c|c|c|c|}
\hline Ecosystem & No. & Country & Region & Method & Time & Source \\
\hline Seagrass & $\begin{array}{l}1 . \\
2 . \\
3 . \\
4 . \\
5 . \\
6 . \\
7 . \\
8 . \\
9 . \\
10 . \\
11 . \\
12 . \\
13 . \\
14 . \\
15 \\
16 . \\
17 . \\
18 . \\
19 . \\
20 . \\
21 . \\
22 . \\
23 . \\
24 . \\
25 \\
26 . \\
27 . \\
28 . \\
29 . \\
30 . \\
31 . \\
32 . \\
33 . \\
34 . \\
35 \\
36 . \\
37 . \\
38 . \\
39 . \\
40 . \\
41 . \\
42 . \\
43 . \\
44 . \\
45 . \\
46 . \\
47 . \\
48 . \\
49 . \\
50 . \\
51 . \\
52 .\end{array}$ & $\begin{array}{l}\text { USA } \\
\text { Australia } \\
\text { USA } \\
\text { USA } \\
\text { USA } \\
\text { USA } \\
\text { USA } \\
\text { Germany } \\
\text { USA } \\
\text { USA } \\
\text { USA } \\
\text { UK } \\
\text { USA } \\
\text { USA } \\
\text { Spain } \\
\text { New Zealand } \\
\text { USA } \\
\text { USA } \\
\text { UK } \\
\text { USA } \\
\text { USA } \\
\text { USA } \\
\text { Spain } \\
\text { USA } \\
\text { USA } \\
\text { USA } \\
\text { USA } \\
\text { Canada } \\
\text { The Philippines } \\
\text { Australia } \\
\text { Puerto Rico } \\
\text { Australia } \\
\text { USA } \\
\text { Australia } \\
\text { Italia } \\
\text { USA } \\
\text { USA } \\
\text { USA } \\
\text { USA } \\
\text { Australia } \\
\text { UK } \\
\text { UK } \\
\text { Australia } \\
\text { USA } \\
\text { Australia } \\
\text { USA } \\
\text { UK } \\
\text { Australia } \\
\text { USA } \\
\text { Australia } \\
\text { Australia } \\
\text { New Zealand }\end{array}$ & $\begin{array}{l}\text { North Carolina } \\
\text { New South Wales } \\
\text { North Carolina } \\
\text { North Carolina } \\
\text { North Carolina } \\
\text { North Carolina } \\
\text { North Carolina } \\
\text { Baltic Sea } \\
\text { Florida } \\
\text { Florida } \\
\text { North Carolina } \\
\text { Devon } \\
\text { North Carolina } \\
\text { California } \\
\text { Alicante } \\
\text { North Island } \\
\text { Florida } \\
\text { Florida } \\
\text { Isles of Scilly } \\
\text { Florida } \\
\text { Virginia } \\
\text { Maine, Florida } \\
\text { Alicante } \\
\text { Florida } \\
\text { Virginia } \\
\text { North Carolina } \\
\text { California, North Carolina } \\
\text { Newfoundland } \\
\text { Bolinao } \\
\text { South Australia } \\
\text { La Parguera } \\
\text { Queensland } \\
\text { California } \\
\text { South Australia } \\
\text { Capo Feto } \\
\text { North Carolina } \\
\text { North Carolina } \\
\text { Texas } \\
\text { California } \\
\text { South Australia } \\
\text { Jersey } \\
\text { Jersey } \\
\text { New South Wales } \\
\text { Alabama, Florida } \\
\text { New South Wales } \\
\text { California } \\
\text { Torbay } \\
\text { Victoria } \\
\text { Mississippi } \\
\text { Victoria } \\
\text { Victoria } \\
\text { South Island }\end{array}$ & $\begin{array}{l}\text { FE } \\
\text { FS, FE, ASU } \\
\text { FE } \\
\text { FE } \\
\text { FE } \\
\text { FS, FE, ASU } \\
\text { FE, ASU } \\
\text { FE } \\
\text { FE } \\
\text { FE, ASU } \\
\text { FE, ASU } \\
\text { FS } \\
\text { FE, ASU } \\
\text { FE } \\
\text { FS } \\
\text { FS } \\
\text { FS, FE, ASU } \\
\text { FS } \\
\text { FS } \\
\text { FE } \\
\text { FS, FE, ASU } \\
\text { FE } \\
\text { FS } \\
\text { FS, FE } \\
\text { FS, FE } \\
\text { FS } \\
\text { FS, FE } \\
\text { FE, ASU } \\
\text { FS } \\
\text { FE, ASU } \\
\text { FS } \\
\text { FS } \\
\text { FE, ASU } \\
\text { FS } \\
\text { FS } \\
\text { FE, ASU } \\
\text { FE, ASU } \\
\text { FS } \\
\text { FE } \\
\text { FS, FE, ASU } \\
\text { FS } \\
\text { FS } \\
\text { FS, FE, ASU } \\
\text { FS, FE, ASU } \\
\text { FS } \\
\text { MO } \\
\text { FS } \\
\text { FS } \\
\text { FS } \\
\text { FE, ASU } \\
\text { FE, ASU } \\
\text { FS }\end{array}$ & $\begin{array}{l}\text { mo-yrs } \\
\text { mo } \\
\text { wk } \\
\text { d-wk } \\
\text { mo } \\
\text { mo } \\
\text { wk } \\
\text { mo } \\
\text { d-wk } \\
\text { wk } \\
\text { wk } \\
\text { d } \\
\text { mo } \\
\text { wk-mo } \\
\text { mo } \\
\text { mo-yr } \\
\text { mo-yr } \\
\text { mo-yr } \\
\text { d } \\
\text { d } \\
\text { d } \\
\text { h-wk } \\
\text { mo-yr } \\
\text { mo } \\
\text { d-wk } \\
\text { yr } \\
\text { h-d } \\
\text { mo-yr } \\
\text { mo } \\
\text { wk-mo } \\
\text { mo } \\
\text { mo-yr } \\
\text { mo } \\
\text { mo } \\
\text { d } \\
\text { d-mo } \\
\text { d-yrs } \\
\text { mo-yrs } \\
\text { mo } \\
\text { wk-mo } \\
\text { d-mo } \\
\text { d-mo } \\
\text { mo } \\
\text { wk-mo } \\
\text { mo-yr } \\
\text { nd } \\
\text { d } \\
\text { mo } \\
\text { mo } \\
\text { d-yr } \\
\text { d-yr } \\
\text { mo }\end{array}$ & $\begin{array}{l}\text { Fonseca et al. (1990) } \\
\text { McNeill \& Fairweather (1993) } \\
\text { Irlandi (1994) } \\
\text { Irlandi et al. (1995) } \\
\text { Irlandi (1996) } \\
\text { Irlandi (1997) } \\
\text { Eggleston et al. (1998) } \\
\text { Reusch (1998) } \\
\text { Bologna \& Heck (1999a) } \\
\text { Bologna \& Heck (1999b) } \\
\text { Eggleston et al. (1999) } \\
\text { Frost et al. (1999) } \\
\text { Irlandi et al. (1999) } \\
\text { Reusch \& Williams (1999) } \\
\text { Sánchez-Jerez et al. (1999) } \\
\text { Turner et al. (1999) } \\
\text { Bologna \& Heck (2000) } \\
\text { Bell et al. (2001) } \\
\text { Bowden et al. (2001) } \\
\text { Brooks \& Bell (2001) } \\
\text { Hovel \& Lipcius (2001) } \\
\text { Peterson et al. (2001) } \\
\text { Barberá-Cebrián et al. (2002) } \\
\text { Bologna \& Heck (2002) } \\
\text { Hovel \& Lipcius (2002) } \\
\text { Hovel et al. (2002) } \\
\text { Hovel (2003) } \\
\text { Laurel et al. (2003) } \\
\text { Salita et al. (2003) } \\
\text { Tanner (2003) } \\
\text { Uhrin \& Holmquist (2003) } \\
\text { Pittman et al. (2004) } \\
\text { Healey \& Hovel (2004) } \\
\text { Tanner (2005) } \\
\text { Fernandez et al. (2005) } \\
\text { Darcy \& Eggleston (2005) } \\
\text { Hovel \& Fonseca (2005) } \\
\text { Burfeind \& Stunz (2006) } \\
\text { Reed \& Hovel (2006) } \\
\text { Tanner (2006) } \\
\text { Jackson et al. (2006a) } \\
\text { Jackson et al. (2006b) } \\
\text { Jelbart et al. (2006) } \\
\text { Johnson \& Heck (2006) } \\
\text { Jelbart et al. (2007) } \\
\text { Hovel \& Regan (2008) } \\
\text { Hirst \& Attrill (2008) } \\
\text { Smith et al. (2008) } \\
\text { Rakocinski et al. (2008) } \\
\text { Warry et al. (2009) } \\
\text { Macreadie et al. (2009) } \\
\text { Mills \& Berkenbusch (2009) }\end{array}$ \\
\hline
\end{tabular}


Appendix 1 (continued)

\begin{tabular}{|c|c|c|c|c|c|c|}
\hline Ecosystem & No. & Country & Region & Method & Time & Source \\
\hline & $\begin{array}{l}53 . \\
54 . \\
55 . \\
56 . \\
57 . \\
58 . \\
59 .\end{array}$ & $\begin{array}{l}\text { Canada } \\
\text { Japan } \\
\text { Thailand } \\
\text { Australia } \\
\text { Australia } \\
\text { Canada } \\
\text { Indonesia }\end{array}$ & $\begin{array}{l}\text { Newfoundland } \\
\text { Moroiso Bay } \\
\text { Trang } \\
\text { Victoria } \\
\text { Victoria } \\
\text { Newfoundland } \\
\text { South Sulawesi }\end{array}$ & $\begin{array}{l}\text { FS, FE } \\
\text { FS } \\
\text { FS } \\
\text { FE, ASU } \\
\text { FS } \\
\text { FS } \\
\text { FS }\end{array}$ & $\begin{array}{l}\mathrm{mo}-\mathrm{yr} \\
\mathrm{mo}-\mathrm{yr} \\
\mathrm{mo}-\mathrm{yr} \\
\mathrm{d} \\
\mathrm{mo} \\
\mathrm{mo}-\mathrm{yr} \\
\mathrm{mo}-\mathrm{yr}\end{array}$ & $\begin{array}{l}\text { Gorman et al. (2009) } \\
\text { Horinouchi (2009) } \\
\text { Horinouchi et al. (2009) } \\
\text { Macreadie et al. (2010) } \\
\text { Smith et al. (2010) } \\
\text { Thistle et al. (2010) } \\
\text { Vonk et al. (2010) }\end{array}$ \\
\hline Salt marsh & $\begin{array}{l}1 . \\
2 . \\
3 . \\
4 . \\
5 . \\
6 . \\
7 . \\
8 . \\
9 . \\
10 . \\
11 . \\
12 . \\
13 . \\
14 . \\
15 . \\
16 . \\
17 . \\
18 . \\
19 . \\
20 . \\
21 . \\
22 . \\
23 . \\
24 . \\
25 . \\
26 . \\
27 . \\
28 . \\
29 . \\
30 . \\
31 . \\
32 . \\
33 . \\
34 . \\
35 . \\
36 . \\
37 . \\
38 . \\
39 .\end{array}$ & $\begin{array}{l}\text { USA } \\
\text { USA } \\
\text { USA } \\
\text { USA } \\
\text { USA } \\
\text { USA } \\
\text { USA } \\
\text { USA } \\
\text { USA } \\
\text { USA } \\
\text { USA } \\
\text { USA } \\
\text { Australia } \\
\text { USA } \\
\text { USA } \\
\text { USA } \\
\text { USA } \\
\text { USA } \\
\text { USA } \\
\text { USA } \\
\text { USA } \\
\text { USA } \\
\text { USA } \\
\text { USA } \\
\text { USA } \\
\text { Australia } \\
\text { USA } \\
\text { USA } \\
\text { USA } \\
\text { USA } \\
\text { USA } \\
\text { Australia } \\
\text { USA } \\
\text { USA } \\
\text { USA } \\
\text { USA } \\
\text { USA } \\
\text { USA } \\
\text { China }\end{array}$ & $\begin{array}{l}\text { Virginia } \\
\text { Louisiana } \\
\text { Louisiana } \\
\text { Georgia } \\
\text { Louisiana } \\
\text { Texas } \\
\text { Virginia } \\
\text { Texas } \\
\text { South Carolina } \\
\text { California } \\
\text { California } \\
\text { Georgia } \\
\text { Queensland } \\
\text { North Carolina } \\
\text { Georgia } \\
\text { Texas } \\
\text { Texas } \\
\text { Georgia } \\
\text { New Jersey } \\
\text { Massachusetts } \\
\text { South Carolina } \\
\text { New England (multiple states) } \\
\text { Louisiana } \\
\text { California } \\
\text { California } \\
\text { Queensland } \\
\text { Virginia } \\
\text { South Carolina } \\
\text { Texas } \\
\text { Texas } \\
\text { California } \\
\text { Queensland } \\
\text { Texas, Louisiana } \\
\text { Massachusetts } \\
\text { California } \\
\text { Georgia } \\
\text { North Carolina } \\
\text { Louisiana } \\
\text { Shanghai } \\
\text { Thana }\end{array}$ & $\begin{array}{c}\text { FS } \\
\text { MO } \\
\text { FS } \\
\text { FE, FS } \\
\text { FS } \\
\text { FE } \\
\text { FS } \\
\text { FS } \\
\text { FS } \\
\text { FS } \\
\text { FS } \\
\text { MO } \\
\text { FS } \\
\text { FS, FE } \\
\text { FS } \\
\text { FS } \\
\text { FS, MO } \\
\text { FS } \\
\text { FS } \\
\text { FS } \\
\text { FS, MO } \\
\text { FS } \\
\text { MO } \\
\text { FS } \\
\text { FS } \\
\text { FS } \\
\text { FE } \\
\text { FS } \\
\text { FS, MO } \\
\text { MO } \\
\text { FS } \\
\text { FS } \\
\text { MO } \\
\text { FE } \\
\text { FE } \\
\text { FS } \\
\text { FS } \\
\text { FS } \\
\text { FS }\end{array}$ & $\begin{array}{c}- \\
\text { mo-yr } \\
\text { yr } \\
\text { d-yr } \\
\text { mo } \\
\text { yr } \\
\text { mo } \\
\text { mo-yr } \\
\text { mo } \\
\text { mo } \\
\text { mo-yr } \\
\text { h-yr } \\
\text { mo } \\
- \\
\text { yr } \\
\text { mo } \\
\text { mo } \\
\text { yr } \\
\text { mo } \\
\text { yrs } \\
\text { yr } \\
\text { yrs } \\
\text { yr } \\
\text { yr } \\
\text { mo } \\
\text { mo } \\
\text { yr } \\
\text { mo-yr } \\
\text { yrs } \\
\text { mo } \\
\text { yrs } \\
\text { yrs } \\
\text { yr } \\
\text { yr } \\
\text { yrs } \\
\text { mo-yrs } \\
\text { mo } \\
\text { mo } \\
\text { mo }\end{array}$ & $\begin{array}{l}\text { Rozas et al. (1988) } \\
\text { Browder et al. (1989) } \\
\text { Baltz et al. (1993) } \\
\text { Kneib (1994) } \\
\text { Peterson \& Turner (1994) } \\
\text { Minello et al. (1994) } \\
\text { Cicchetti \& Diaz (2000) } \\
\text { Rozas \& Zimmerman (2000) } \\
\text { Lerberg et al. (2000) } \\
\text { Desmond et al. (2000) } \\
\text { West \& Zedler (2000) } \\
\text { Kneib (2000) } \\
\text { Thomas \& Connolly (2001) } \\
\text { Lewis \& Eby (2002) } \\
\text { Webb \& Kneib (2002) } \\
\text { Whaley \& Minello (2002) } \\
\text { Minello \& Rozas (2002) } \\
\text { Kneib (2003) } \\
\text { Able et al. (2003) } \\
\text { Palmer (2004) } \\
\text { Holland et al. (2004) } \\
\text { Shriver et al. (2004) } \\
\text { Haas et al. (2004) } \\
\text { Dean et al. (2005) } \\
\text { Visintainer et al. (2006) } \\
\text { Guest \& Connolly (2006) } \\
\text { Long \& Burke (2007) } \\
\text { Allen et al. (2007) } \\
\text { Rozas et al. (2007) } \\
\text { Minello et al. (2008) } \\
\text { Kelly et al. (2008) } \\
\text { Meynecke et al. (2008) } \\
\text { Roth et al. (2008) } \\
\text { Fleeger et al. (2008) } \\
\text { Larkin et al. (2008) } \\
\text { Kneib (2009) } \\
\text { Meyer \& Posey (2009) } \\
\text { Rozas \& Minello (2010) } \\
\text { Jin et al. (2010) }\end{array}$ \\
\hline Coral reef & $\begin{array}{l}1 . \\
2 . \\
3 . \\
4 . \\
5 . \\
6 . \\
7 . \\
8 . \\
9 . \\
10 . \\
11 . \\
12 . \\
13 .\end{array}$ & $\begin{array}{l}\text { USA } \\
\text { USA } \\
\text { Australia } \\
\text { Australia } \\
\text { Australia } \\
\text { Australia } \\
\text { Belize } \\
\text { USA \& British } \\
\text { Africa } \\
\text { Bahamas } \\
\text { USA \& British } \\
\text { Japan } \\
\text { USA \& British }\end{array}$ & $\begin{array}{l}\text { California } \\
\text { Virgin \& Marshall Islands } \\
\text { Queensland } \\
\text { Queensland } \\
\text { Queensland } \\
\text { Queensland } \\
\text { Glovers Reef } \\
\text { Virgin Islands } \\
\text { Zanzibar } \\
\text { Lee Stocking Island } \\
\text { Virgin Islands } \\
\text { Okinawa } \\
\text { Virgin Islands }\end{array}$ & $\begin{array}{l}\text { FE, FS } \\
\text { FS } \\
\text { FS } \\
\text { FS } \\
\text { FS } \\
\text { FE } \\
\text { FS } \\
\text { FS } \\
\text { FS } \\
\text { FE } \\
\text { FS } \\
\text { FS } \\
\text { FS }\end{array}$ & $\begin{array}{c}\mathrm{yr} \\
\mathrm{d}-\mathrm{wk} \\
\mathrm{mo}-\mathrm{yr} \\
\mathrm{yr} \\
\mathrm{yr} \\
\mathrm{d}-\mathrm{mo} \\
\mathrm{mo} \\
\mathrm{mo}-\mathrm{yr} \\
\mathrm{wk}-\mathrm{mo} \\
\mathrm{h}-\mathrm{mo} \\
\text { mo } \\
\text { mo-yr } \\
\text { mo-yr }\end{array}$ & $\begin{array}{l}\text { Molles (1978) } \\
\text { Gladfelter et al. (1980) } \\
\text { Sale \& Douglas (1984) } \\
\text { Ault \& Johnson (1998a) } \\
\text { Ault \& Johnson (1998b) } \\
\text { Caley et al. (2001) } \\
\text { Acosta \& Robertson (2002) } \\
\text { Chittaro (2002) } \\
\text { Dorenbosch et al. (2005) } \\
\text { Overholtzer-McLeod (2006) } \\
\text { Grober-Dunsmore et al. (2007) } \\
\text { Hattori \& Kobayashi (2007) } \\
\text { Grober-Dunsmore et al. (2008) }\end{array}$ \\
\hline Mangrove & $\begin{array}{l}1 . \\
2 . \\
3 . \\
4 . \\
5 . \\
6 . \\
7 .\end{array}$ & $\begin{array}{l}\text { USA \& British } \\
\text { Australia } \\
\text { Malaysia } \\
\text { Puerto Rico } \\
\text { UK } \\
\text { USA } \\
\text { Australia }\end{array}$ & $\begin{array}{l}\text { Virgin Islands } \\
\text { Queensland } \\
\text { Western peninsular Malaysia } \\
\text { La Paguera } \\
\text { Cayman Islands } \\
\text { Florida } \\
\text { Queensland }\end{array}$ & $\begin{array}{l}\text { FS } \\
\text { FS } \\
\text { FS } \\
\text { FS } \\
\text { FS } \\
\text { FS } \\
\text { FS }\end{array}$ & $\begin{array}{l}\text { wk } \\
\text { yr } \\
\text { yr } \\
\text { mo-yrs } \\
\text { d } \\
\text { mo-yrs } \\
\text { yr }\end{array}$ & $\begin{array}{l}\text { Halpern (2004) } \\
\text { Manson et al. (2005) } \\
\text { Loneragan et al. (2005) } \\
\text { Pittman et al. (2007) } \\
\text { Marlow et al. (2007) } \\
\text { Drew \& Eggleston (2008) } \\
\text { Meynecke et al. (2008) }\end{array}$ \\
\hline Oyster reef & $\begin{array}{l}1 . \\
2 .\end{array}$ & $\begin{array}{l}\text { USA } \\
\text { USA }\end{array}$ & $\begin{array}{l}\text { North Carolina } \\
\text { North Carolina }\end{array}$ & $\begin{array}{l}\mathrm{FE} \\
\mathrm{FE}\end{array}$ & $\begin{array}{l}\text { wk-mo } \\
\text { wk }\end{array}$ & $\begin{array}{l}\text { Eggleston et al. (1998) } \\
\text { Eggleston et al. (1999) }\end{array}$ \\
\hline Total & 118 & & & & & \\
\hline
\end{tabular}

